\title{
European beech stem diameter grows better in mixed than in mono-specific stands at the edge of its distribution in mountain forests
}

\author{
Hans Pretzsch ${ }^{1}$ (D) Torben Hilmers $^{1} \cdot$ Enno Uhl $^{1,2} \cdot$ Kamil Bielak $^{3} \cdot$ Michal Bosela $^{4,5} \cdot$ Miren del Rio $^{6,7} \cdot$ Laura Dobor $^{8}$. \\ David I. Forrester ${ }^{9}$. Thomas A. Nagel ${ }^{10} \cdot$ Maciej Pach ${ }^{11} \cdot$ Admir Avdagić $^{12} \cdot$ Michal Bellan $^{13,14} \cdot$ Franz Binder $^{2}$. \\ Andrej Bončina ${ }^{10}$. Felipe Bravo ${ }^{7}$. Javier de-Dios-García ${ }^{15}$. Lucian Dinca ${ }^{16}$. Stanisław Drozdowski ${ }^{3}$. \\ Francesco Giammarchi ${ }^{17}$ - Maria Hoehn ${ }^{18}$. Aida Ibrahimspahić ${ }^{12}$. Andrzej Jaworski ${ }^{11}$ - Matija Klopčič ${ }^{10}$. \\ Viktor Kurylyak $^{19}$ - Mathieu Lévesque ${ }^{20}$. Fabio Lombardi ${ }^{21}$ - Bratislav Matović ${ }^{22,23}$. Cristóbal Ordóñez ${ }^{7,24}$. \\ Rudolf Petráśs ${ }^{25}$. Alvaro Rubio-Cuadrado ${ }^{26}$. Dejan Stojanovic ${ }^{22}$. Jerzy Skrzyszewski ${ }^{11}$ • Branko Stajić B $^{27}$. \\ Mirolav Svoboda ${ }^{8} \cdot$ Soraya Versace $^{28} \cdot$ Tzvetan Zlatanov $^{29} \cdot$ Roberto Tognetti $^{30}$
}

Received: 7 May 2020 / Revised: 4 September 2020 / Accepted: 8 September 2020 / Published online: 25 September 2020

(c) The Author(s) 2020

\begin{abstract}
Recent studies show that several tree species are spreading to higher latitudes and elevations due to climate change. European beech, presently dominating from the colline to the subalpine vegetation belt, is already present in upper montane subalpine forests and has a high potential to further advance to higher elevations in European mountain forests, where the temperature is predicted to further increase in the near future. Although essential for adaptive silviculture, it remains unknown whether the upward shift of beech could be assisted when it is mixed with Norway spruce or silver fir compared with mono-specific stands, as the species interactions under such conditions are hardly known. In this study, we posed the general hypotheses that the growth depending on age of European beech in mountain forests was similar in mono-specific and mixed-species stands and remained stable over time and space in the last two centuries. The scrutiny of these hypotheses was based on increment coring of 1240 dominant beech trees in 45 plots in mono-specific stands of beech and in 46 mixed mountain forests. We found that (i) on average, mean tree diameter increased linearly with age. The age trend was linear in both forest types, but the slope of the age-growth relationship was higher in mono-specific than in mixed mountain forests. (ii) Beech growth in mono-specific stands was stronger reduced with increasing elevation than that in mixed-species stands. (iii) Beech growth in mono-specific stands was on average higher than beech growth in mixed stands. However, at elevations $>1200 \mathrm{~m}$, growth of beech in mixed stands was higher than that in mono-specific stands. Differences in the growth patterns among elevation zones are less pronounced now than in the past, in both mono-specific and mixed stands. As the higher and longer persisting growth rates extend the flexibility of suitable ages or size for tree harvest and removal, the longer-lasting growth may be of special relevance for multi-aged silviculture concepts. On top of their function for structure and habitat improvement, the remaining old trees may grow more in mass and value than assumed so far.
\end{abstract}

Keywords Age-dependent tree growth $\cdot$ Inter-specific facilitation $\cdot$ Intra-specific competition $\cdot$ Climate change $\cdot$ Growth trends · Growth acceleration

Communicated by Claus Bässler.

Electronic supplementary material The online version of this article (https://doi.org/10.1007/s10342-020-01319-y) contains supplementary material, which is available to authorized users.

Hans Pretzsch

Hans.Pretzsch@tum.de

Extended author information available on the last page of the article

\section{Introduction}

For many tree species living on the edge of their distribution regarding longitude, latitude or elevation becomes increasingly difficult under climate change. Because of their multiple protection functions and ecosystem services, mountain forests demand high attention by global change research and require climate-smart forest management practices 
(Bowditch et al. 2020). Due to the strong elevation gradients, many mountain regions provide unique opportunities to detect and analyse global change processes and phenomena (Becker and Bugmann 2001; Hernández et al. 2019). European beech (Fagus sylvatica L.; hereafter referred to as beech) is one of the most important and successful tree species in Europe (Leuschner et al. 2006) and contributes a high economic and ecological value across lowland, upland and mountain regions (Eurostat 2018). Numerous recent studies report that, due to strong competitiveness and environmental plasticity of beech, this species would dominate many forested regions in Central Europe without human influence (Sykes and Prentice 1995; Körner 2005; Bolte et al. 2007; Schuldt et al. 2016; Dyderski et al. 2018). However, there are also critical voices doubting the dominance of beech without humans due to an enhanced growth of beech since 1950 that can be primarily attributed to human influences like nitrogen fertilization or management effects (Scharnweber et al. 2011, 2019). Its dominance was reduced in the past for economic reasons, particularly in Central Europe, but its high mechanical stability against windthrow and comparatively high resistance and resilience to drought are leading to a comeback in view of climate change (Pretzsch et al. 2020a; Paul et al. 2019; Hanewinkel et al. 2011). Presently beech forests cover about $12 \times 10^{6}$ ha in Europe (Brus et al. 2012), and the area is steeply increasing due to a transition to close-to-nature forestry. The current growth trends of beech and its response to stress events are important for a realistic assessment of its potential under future climate change.

Although the gross primary productivity of beech stands may benefit from warming due to the earlier foliage formation (Collalti et al. 2018), beech may also suffer from repeated and prolonged drought episodes (Tognetti et al. 1994, 2019), ice storms (Klopčič et al. 2019) and late frost (Vitasse et al. 2014; Bigler and Bugmann 2018). Furthermore, the growth responses to changes in temperature and precipitation may depend on elevation; e.g. drought stress is less likely in higher elevations with ample precipitation (Trotsiuk et al. 2020).

The downregulation of photosynthesis after the extreme drought and heat wave, which hit Central Europe in the summer of 2003, reduced the productivity of beech forests (Bosela et al. 2018; Leuzinger et al. 2005; van der Werf et al. 2007). A decline in beech productivity in response to drought stress was also recorded in Mediterranean Europe (Jump et al. 2006; Piovesan et al. 2008), though populationspecific vulnerability to drought might be mitigated to some extent by acclimation (Dittmar et al. 2003; Pretzsch et al. 2020a; Tegel et al. 2014; Tognetti et al. 2014). Similarly, beech provenances may exhibit distinct drought vulnerability and resistance (Bolte et al. 2016; Cocozza et al. 2016). Given that beech has a competitive ability in various soil conditions and a phenotypic plasticity in response to environmental disturbances (Liu et al. 2017; Stojnić et al. 2018), it may recover photosynthesis and growth after stress episodes by adjusting stomatal conductance (Tognetti et al. 1995; Gallé and Feller 2007; Zang et al. 2014; Pflug et al. 2018).

In the centre of its natural range, with a climate envelope between 450 and $1500 \mathrm{~mm}$ annual precipitation and mean annual temperature $3-12.5^{\circ} \mathrm{C}$, beech presently grows well and achieves higher stand productivity compared with the growth rates in the past (Spiecker et al. 2012; Pretzsch et al. 2014a; Pretzsch 2020). Since the 1960s the annual volume growth increasingly exceeded predictions from yield tables by $5-77 \%$ from east to west, respectively (Pretzsch et al. 2014a; Bosela et al. 2016). However, a series of dry years (e.g. 2003, 2015) with occasional drought-induced beech mortality reduced the increasing trend (Kohnle et al. 2014). Bosela et al. (2018) also reported a growth decrease in the recent past with high frequency of drought years. Presently, the growth acceleration is interrupted by drought events, but even in dry years, growth is still far above historical levels.

This specific growth pattern, when growth slumps but at a level far above the past (Pretzsch et al. 2020b), contributed to a very controversial discussion about the potential of beech under climate change in the future. Geßler et al. (2007) and Rennenberg et al. (2004) saw no future for beech in Europe under climate change, whereas Ammer et al. (2005) and Bolte et al. (2010) pointed out the high vitality and fitness of the species, and Schuldt et al. (2016) the notable ability of beech to acclimate and adapt to climate change. Moreover, forest management (i.e. management vs. no management) may strongly change the potential of beech to cope with future climatic conditions (Bosela et al. 2016; Mausolf et al. 2018).

The growth and distribution of beech at the northern and eastern edge of its distribution are mainly limited by low temperatures and drought (Hacket-Pain et al. 2018), late frost (Vitasse et al. 2014; Bigler and Bugmann 2018) and water logging or flooding (Scharnweber et al. 2013; Kreuzwieser and Rennenberg 2014). Growth responses to climate warming will also depend on how its reproduction is influenced (Hacket-Pain et al. 2018). At the southern edge, it is limited by heat and drought (Jump et al. 2006). Consequently, a change of climate towards a more temperate climate, in the former boreal and continental north and east, and a Mediterranean climate at the southern fringe, may strongly affect the growth and distribution of beech.

There are reports of reductions in beech presence in the Spanish lowlands and expansions of beech towards the mountain areas (Buras and Menzel 2019; Rabasa et al. 2013). In Scandinavia (Drobyshev et al. 2010) and Poland (Bolte et al. 2007) beech seems to be on the advance (Bolte et al. 2007; Poljanec et al. 2010). In Central Europe, beech at present shows higher absolute growth rates compared with the historic level (Pretzsch et al. 2014a; Dulamsuren 
et al. 2017). Nevertheless, its sensitivity to drought (Bosela et al. 2016), atmospheric ozone concentration (Pretzsch et al. 2010; Wipfler et al. 2005) and late frost (Vitasse et al. 2014) is very high.

Zeller and Pretzsch (2019) found that the overyielding due to niche complementarity and vertical structuring increases with stand development phase and age. Juchheim et al. (2017) stressed the superior morphological plasticity of beech crowns that supports their light interception and growth. Beech may benefit from spatial niche complementarity and light interception when mixed with other species such as Scots pine (Gonzalez de Andres et al. 2017), Norway spruce (Pretzsch et al. 2014b), Douglas-fir (Thurm and Pretzsch 2016) and silver fir (Bosela et al. 2015; Jourdan et al. 2019). Goisser et al. (2016) and Pretzsch et al. (2020a) indicated a temporal complementarity, possibly due to more favourable water and light use, when growing in mixture with conifer species.

Several studies showed that drought effects can be reduced by admixture of European beech (Lebourgeois et al. 2013; Pretzsch et al. 2013; Forrester 2015; Jourdan et al. 2019). Further empirical research showed the capacity of beech to acclimate and recover after drought (Camarero et al. 2018; Pretzsch and Schütze 2018) and its ability to recover after ozone exposure (Matyssek et al. 2010). Simulation studies with process-based models corroborate these stress reaction patterns of European beech (Gonzalez de Andres et al. 2017; Kramer et al. 2010; Magh et al. 2019; Rötzer et al. 2013). Given that the main silvicultural treatment of beech stands is a heavy thinning from above to promote the growth and quality of a selected number of crop trees, drought stress may be reduced by the rather strong stand density reductions (Giuggiola et al. 2013; Trouvé et al. 2017).

Whether the predicted shift of the range and optimum of beech to northern latitudes coincides with a shift to higher elevations in mountain forests is still open for debate. It depends on both a possible improvement of the growing conditions for beech at higher elevations and the climate sensitivity and fitness of the species currently dominating in the potential new territory of beech at higher elevations in the mountains. In many Alpine regions, the upper limit of beech distribution is the mixed mountain forests of Norway spruce, silver fir and beech. Thus, any upwards shift of beech depends on both the change of the growing conditions (increase in temperature, late frost occurrence) at the elevation of 600-1600 $\mathrm{m}$ a.s.l. and a change in the inter-specific competition between the three species in these mixed mountain forests. In the Apennines, Pyrenees and the Mountains of the Balkan peninsula, land use can be the prevailing factor influencing the upward shift of beech up to and beyond the subalpine belt (Cudlín et al. 2017, Vukelić et al. 2008).

To examine whether species mixing influences the growth response of beech along elevation gradients, we sampled increment cores from 1240 beech trees from mono-specific and mixed forest stands along an elevation gradient in 14 European countries. That on average mixed mountain forests in Europe have a mixing proportion of beech of $20-30 \%$ (Brus et al. 2012) means that a considerable part of the total beech stock occurs in mountain areas. We used this rather unique cross-regional data set to pose the general hypotheses that the growth pattern depending on tree age of European beech is similar in mono-specific and mixed-species stands and remained stable over time and space in the last two centuries. To scrutinize this hypothesis, we answered the following questions:

Q1 Does the age trend of diameter growth differ between mixed and mono-specific stands?

Q2 How does the present diameter growth compare with the past; are there any changes in age-related tree growth?

Q3 Are the elevation-dependent growth trends different in mixed compared with mono-specific stands?

\section{Materials and methods}

\section{Material}

\section{Observational plots, site conditions, sample sizes}

For the study we selected 91 fully stocked, unthinned or slightly thinned forest stands distributed across Europe (Fig. 1, Supplement Table 1) that reflected natural dynamics and climatic variation. In mixed plots, beech was mainly mixed with Norway spruce (Picea abies L.) and silver fir (Abies alba Mill.), but studied plots included other admixed species, such as Scots pine (Pinus sylvestris L.), sycamore maple (Acer pseudoplatanus L.), European larch (Larix decidua Mill.) and European hornbeam (Carpinus betulus L.). Except for Scots pine and sycamore maple, these minority species, however, represented less than $10 \%$ of the stand basal area across all plots.

All the study sites are located in mountain regions, from Picos de Europa (Spain) in the west to the Southern Carpathians (Romania) in the east and from the Tatras (Poland) in the north to the Apennines (Italy) in the south. Elevations vary from around $500 \mathrm{~m}$ a.s.1. to more than $1500 \mathrm{~m}$ a.s.1., both in mono-specific and mixed stands. The sites cover a large range of climate conditions with mean temperatures between 2.6 and $10.2{ }^{\circ} \mathrm{C}$ and annual precipitation between 517 and $2780 \mathrm{~mm}$ (Fig. 2). Monthly mean temperature and precipitation sum were prepared for the period of 1901-2016 for the study plots based on the closest meteorological stations and the CRU TS 4.01 gridded observation-based 


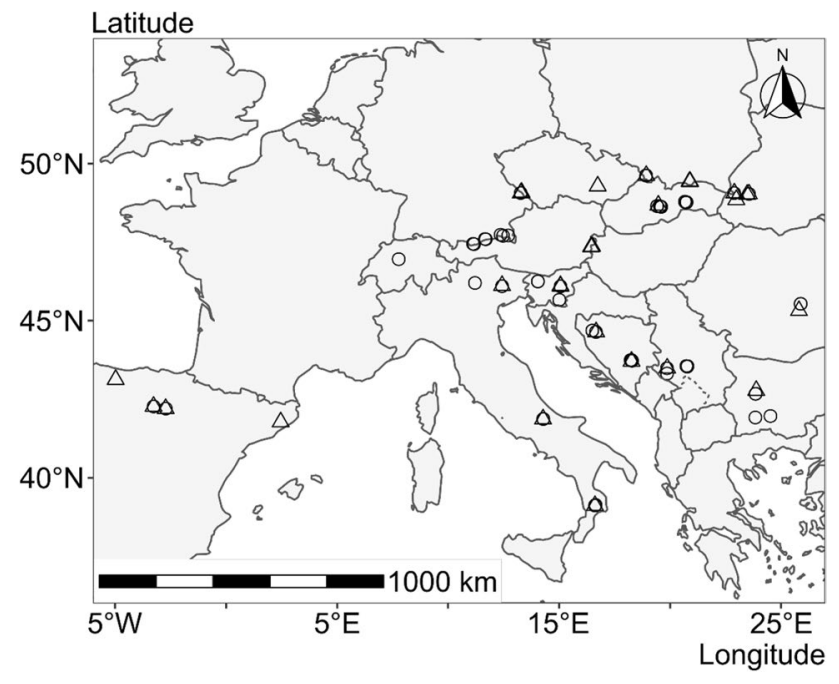

Fig. 1 Location of the 46 observational plots in mixed mountain forests (circles) and 45 observational plots in mono-specific stands of beech in mountain areas (triangles) of 14 countries where increment cores of beech were sampled for this study. The study covered mountain forests in Bosnia and Herzegovina, Bulgaria, Czechia, Germany, Hungary, Italy, Poland, Romania, Serbia, Slovakia, Slovenia, Spain, Ukraine and Switzerland

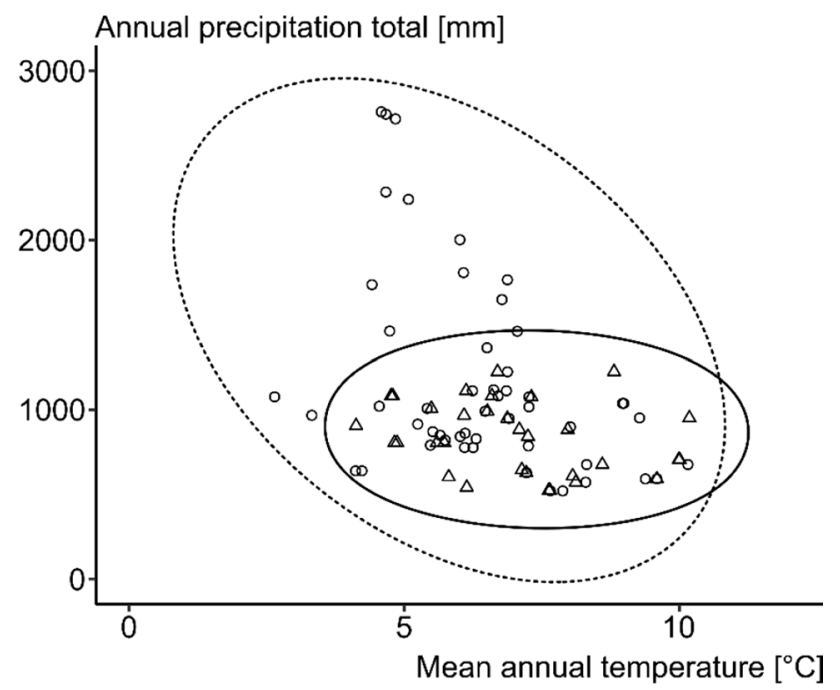

Fig. 2 Scatter plot of annual precipitation total in $\mathrm{mm}$ and mean annual temperature in ${ }^{\circ} \mathrm{C}$ of the 46 observational plots in mixed mountain forests (circles) and 45 observational plots in mono-specific stands of beech (triangles). Ellipses represent a convex hull of the mono-specific plots (solid line) and mixed-species plots (dashed)

dataset (Harris et al. 2020). As station datasets did not cover the targeted period for all plots, the gaps were filled by fitted CRU data. Based on the period where both station and CRU data were available, correction factors were defined and applied to the whole length of CRU data to fit them to the station data. The resulting dataset combined station data and fitted CRU for all study plots without discontinuity on a monthly scale.

\section{Tree measurement protocol and core sampling}

Increment cores were collected from dominant beech trees in each plot. The stem diameter at breast height $(1.3 \mathrm{~m}$, $\mathrm{dbh}$ ) was measured using a tape (in $\mathrm{mm}$ ), the tree height and height to live crown base were measured using a hypsometer Vertex (in decimetre). The height to live crown base was defined as the distance from ground to the lowest living primary branch. We further measured the crown radii in 4-8 directions (N, NE, E, ..., NW) in decimetres.

From each tree, we took two $5.15 \mathrm{~mm}$ diameter cores at $1.3 \mathrm{~m}$, in the north and east directions, with a standard increment corer (Haglöf Mora Coretax). The increment cores were air-dried, mounted and glued on wooden supports and subsequently sanded using sandpaper with progressively finer grit. We applied a careful visual procedure for making sure the sampled trees were not only dominant at the time of sampling but also in the past. First, if longer suppression phases were clearly discernible on the wood sample immediately after coring in the field, the sample was not included in this study, and an alternative tree was selected. Second, after the ring widths were measured, we plotted the empirical growth curves for visual examination. About $5 \%$ of the trees were excluded at that stage due to their growth curves showing depression phases of 10 years and more. In order to avoid sample trees with suppression phases prior to canopy recruitment, we excluded all trees with longer low growth phases, as described by Pretzsch (2009).

\section{Tree ring analyses and overview of tree ring data}

Tree ring widths were measured to the nearest $1 / 100 \mathrm{~mm}$ using a digital positioning table (Kutschenreiter and Johann; Digitalpositiometer, Britz and Hatzl GmbH, Austria). We measured the annual ring widths on each core and crossdated the individual time series. The radial increments, ir, of the two cores of a tree $\left(\mathrm{ir}_{1}, \mathrm{ir}_{2}\right)$ were added to obtain a representative time series of diameter increment, id, for each tree $\left(\mathrm{id}=\mathrm{ir}_{1}+\mathrm{ir}_{2}\right)$.

For those trees whose cores did not reach the pith, the age was estimated from the sum of the number of growth rings (NGR) of the core and an estimate of the missing number of growth rings by applying the formula Age $=\mathrm{NGR}_{\text {core }}+\mathrm{NGR}_{\text {missing }}$. The number of missing rings was estimated by dividing the last known diameter by the mean diameter increment of the first 15 years. Age was estimated for $73 \%$ of all trees using this method. However, all trees with estimations of more than 30 missing growth rings were removed from the dataset. Table 1 provides an overview of the tree ring data used for this study. 
Table 1 Overview of the tree ring data used for this study

\begin{tabular}{|c|c|c|c|c|c|c|c|c|c|c|c|c|}
\hline \multirow[t]{2}{*}{ Country } & \multirow[t]{2}{*}{ Composition } & \multirow[t]{2}{*}{ No. plots } & \multirow[t]{2}{*}{ No. trees } & \multicolumn{3}{|c|}{$\mathrm{dbh}(\mathrm{cm})$} & \multicolumn{3}{|c|}{ Age (years) } & \multicolumn{3}{|c|}{$\begin{array}{l}\text { Diameter increment }(\mathrm{mm} / \\
\text { year) }\end{array}$} \\
\hline & & & & Min & Median & $\operatorname{Max}$ & Min & Median & Max & Min & Median & Max \\
\hline Bosnia & Mono & 5 & 51 & 29.6 & 36.0 & 53.2 & 53 & 87 & 351 & 0.12 & 3.11 & 16.09 \\
\hline Bulgaria & Mono & 1 & 10 & 34.5 & 40.0 & 49.5 & 85 & 99 & 121 & 0.34 & 3.73 & 12.46 \\
\hline Czech Republic & Mono & 4 & 36 & 35.0 & 44.9 & 83.3 & 80 & 112 & 389 & 0.01 & 2.49 & 12.88 \\
\hline Germany & Mono & 2 & 20 & 34.3 & 41.9 & 58.7 & 79 & 92 & 116 & 0.58 & 4.46 & 11.52 \\
\hline Hungary & Mono & 2 & 20 & 38.0 & 41.8 & 46.6 & 70 & 91 & 107 & 0.36 & 4.34 & 13.32 \\
\hline Italy & Mono & 4 & 39 & 26.0 & 46.5 & 81.8 & 73 & 121 & 212 & 0.12 & 3.12 & 18.08 \\
\hline Poland & Mono & 6 & 60 & 32.2 & 47.4 & 66.8 & 66 & 124 & 263 & 0.11 & 3.68 & 12.95 \\
\hline Romania & Mono & 2 & 20 & 35.1 & 43.4 & 56.9 & 75 & 95 & 118 & 0.50 & 4.32 & 12.19 \\
\hline Serbia & Mono & 4 & 33 & 19.2 & 42.8 & 81.3 & 93 & 188 & 299 & 0.16 & 2.34 & 12.32 \\
\hline Slovakia & Mono & 2 & 20 & 32.6 & 47.1 & 64.3 & 77 & 102 & 122 & 0.85 & 4.40 & 11.33 \\
\hline Slovenia & Mono & 2 & 20 & 46.8 & 51.6 & 63.2 & 116 & 175 & 308 & 0.17 & 2.86 & 10.06 \\
\hline Spain & Mono & 7 & 65 & 25.6 & 36.3 & 50.9 & 56 & 128 & 289 & 0.01 & 2.26 & 16.85 \\
\hline Ukraine & Mono & 4 & 40 & 40.5 & 49.1 & 84.4 & 66 & 102 & 308 & 0.06 & 4.08 & 15.24 \\
\hline Bosnia & Mixed & 3 & 50 & 19.1 & 48.2 & 62.1 & 65 & 192 & 389 & 0.12 & 2.50 & 15.57 \\
\hline Bulgaria & Mixed & 4 & 66 & 23.0 & 36.0 & 56.6 & 55 & 106 & 151 & 0.18 & 3.10 & 13.87 \\
\hline Germany & Mixed & 8 & 153 & 25.2 & 44.9 & 95.2 & 84 & 167 & 375 & 0.12 & 2.25 & 15.10 \\
\hline Italy & Mixed & 5 & 42 & 22.0 & 45.9 & 73.0 & 64 & 121 & 210 & 0.18 & 3.52 & 16.58 \\
\hline Poland & Mixed & 2 & 20 & 33.3 & 36.6 & 51.5 & 74 & 86 & 114 & 0.49 & 4.19 & 12.05 \\
\hline Romania & Mixed & 1 & 10 & 29.0 & 31.7 & 40.2 & 100 & 109 & 154 & 0.12 & 2.64 & 11.06 \\
\hline Serbia & Mixed & 5 & 91 & 33.3 & 50.0 & 75.4 & 56 & 144 & 353 & 0.01 & 3.38 & 15.00 \\
\hline Slovakia & Mixed & 8 & 270 & 16.8 & 40.7 & 94.6 & 65 & 130 & 316 & 0.01 & 2.40 & 29.22 \\
\hline Slovenia & Mixed & 5 & 54 & 31.1 & 47.0 & 79.7 & 110 & 154 & 365 & 0.12 & 2.47 & 13.64 \\
\hline Spain & Mixed & 2 & 20 & 24.5 & 32.2 & 40.9 & 66 & 89 & 145 & 0.20 & 3.33 & 12.03 \\
\hline Switzerland & Mixed & 1 & 9 & 40.9 & 49.9 & 68.8 & 74 & 111 & 160 & 0.36 & 3.68 & 16.78 \\
\hline Ukraine & Mixed & 2 & 21 & 42.0 & 57.6 & 79.9 & 85 & 130 & 214 & 0.15 & 3.57 & 12.86 \\
\hline
\end{tabular}

The table presents the whole dataset, which was used for fitting the models according to Eqs. 2-5. Dbh and age are related to the year 2017. Note that for fitting the model according to Eqs. 2, 3 and 5, we eliminated all trees with more than 30 missing growth rings

\section{Statistical evaluation}

\section{Linearity of diameter growth over age}

Visualization of the diameter growth over the last centuries generally showed a non-sigmoid linear growth trend (Pretzsch et al. 2020b). Therefore, to test the past diameter growth over age for linearity versus nonlinearity, we used the following simple model

$\mathrm{dbh}=k \cdot \mathrm{AGE}^{a 1}$

which is equivalent to

$\ln (\mathrm{dbh})=a_{0}+a_{1} \cdot \ln (\mathrm{AGE}) \quad$ with $a_{0}=\ln (k)$

where AGE is tree age (years), $k$ is a scaling parameter and $a_{1}$ is the exponent-which is most crucial for our research question. When $a_{1}=1$, Eq. 1 describes linear growth. When $a_{1}<1$ or $a_{1}>1$, the equation describes nonlinear growth, with decreasing or increasing growth rates, respectively. This was applied to the full data set, but separately for beech in mono-specific stands and beech in mixed mountain forests, by way of a linear mixed-effects model, as follows:

$$
\begin{aligned}
\ln \left(\mathrm{dbh}_{i j k}\right)= & a_{0}+a_{1} \cdot \ln \left(\mathrm{AGE}_{i j k}\right)+b_{i}+b_{i j}+\left(c_{i}+c_{i j}\right) . \\
& \ln \left(\mathrm{AGE}_{i j k}\right)+\varepsilon_{i j k} .
\end{aligned}
$$

The fixed effect parameters $a_{0}$ and $a_{1}$ have exactly the same meaning as in Eq. $1 \mathrm{~b}$; if $a_{1}$ is not significantly different from 1 , we would assume a linear growth process. The indexes $i, j, k$ in Eq. 2 refer to the levels of plot, tree within plot and single observation, respectively. In order to account for autocorrelation, random effects $b$ and $\mathrm{c}$ were applied on the levels of plot and tree in the plot. Whereas the former considered any spatial dependencies between the trees on the same plot, the latter considered the temporal autocorrelation between successive growth records from the same 
tree. While the random effect $b$ relates to the intercept $a_{0}$, the random effect $c$ refers to the slope $a_{1}$. All random effects were assumed to be normally distributed with an expected mean of 0 . The uncorrelated remaining errors are $\varepsilon_{i j k}$.

\section{Diameter growth and elevation}

The test using Eq. 2 indicated linear diameter growth over age; therefore, we used the following linear mixed-effects model to investigate whether the steepness of the diameter-age relationship differs between beech trees from monospecific stands and beech trees from mixed stands and how the relationship changed with elevation: and mean temperature and is easy to interpret, this index has been frequently used in climate change research.

$$
\begin{aligned}
\text { deMARTONNE }= & \text { annual precipitation/ } \\
& (\text { annual mean temperature }+10) .
\end{aligned}
$$

We added mean annual temperature and the de Martonne aridity index (Bielak et al. 2014; Pretzsch et al. 2015a, b) to our model, as elevation is not sufficient for characterizing the site-specific growth conditions along elevation gradients (Khurshid-Alam 1972; Lauscher 1976; Körner 2003).

The fixed effects in this model cover the main effects $\ln (\mathrm{AGE})$, ELEVATION, MAT, deMARTONNE, MixMono and all their two-way interactions. Mixed effect models were

$$
\begin{aligned}
& \ln \left(\mathrm{dbh}_{i j k}\right)=a_{0}+a_{1} \cdot \ln \left(\mathrm{AGE}_{i j k}\right)+a_{2} \cdot \operatorname{ELEVATION}_{i j}+a_{3} \cdot \mathrm{MAT}_{i j}+a_{4} \cdot \operatorname{deMARTONNE}_{i j} \\
& +a_{5} \cdot \mathrm{MixMono}_{i j}+a_{6} \cdot \ln \left(\mathrm{AGE}_{i j k}\right) \cdot \mathrm{ELEVATION}_{i j}+a_{7} \cdot \ln \left(\mathrm{AGE}_{i j k}\right) \cdot \mathrm{MAT}_{i j} \\
& +a_{8} \cdot \ln \left(\mathrm{AGE}_{i j k}\right) \cdot \operatorname{deMARTONNE}_{i j}+a_{9} \cdot \ln \left(\mathrm{AGE}_{i j k}\right) \cdot \mathrm{MixMono}_{i j}+a_{10} \\
& \cdot \text { ELEVATION }_{i j} \cdot \text { MeanTemp }_{i j}+a_{11} \cdot \text { ELEVATION }_{i j} \cdot \operatorname{deMARTONNE}_{i j}+a_{12} \\
& \cdot \text { ELEVATION }_{i j} \cdot \text { MixMono }_{i j}+a_{13} \cdot \mathrm{MAT}_{i j} \cdot \operatorname{deMARTONNE}_{i j}+a_{14} \cdot \mathrm{MAT}_{i j} \\
& \cdot \text { MixMono }_{i j}+a_{15} \cdot \operatorname{deMARTONNE}_{i j} \cdot \text { MixMono }_{i j}+b_{i}+b_{i j}+\left(c_{i}+c_{i j}\right) \\
& \cdot \ln \left(\mathrm{AGE}_{i j k}\right)+\varepsilon_{i j k} \text {. }
\end{aligned}
$$

The meaning of the notation is the same as in Eq. 2. The only new variables were the fixed effect MixMono (0: mono-specific; 1: mixed), ELEVATION, MAT and deMARTONNE, which stands for a given species composition in the plot, elevation above sea level in $\mathrm{m}$, mean annual temperature in ${ }^{\circ} \mathrm{C}$ and the de Martonne aridity index (de Martonne 1926). As it only requires records of annual precipitation computed using the R package nlme (Pinheiro et al. 2020; R Core Team 2020).

\section{Temporal growth trends and elevation}

For investigating temporal trends concerning the steepness of the diameter-age relationship and how this changed with elevation and species composition, we used the following linear mixed-effects model, which can be seen as an extended model of Eq. 3:

$$
\begin{aligned}
& \ln \left(\mathrm{dbh}_{i j k}\right)=a_{0}+a_{1} \cdot \ln \left(\mathrm{AGE}_{i j k}\right)+a_{2} \cdot \text { ELEVATION }_{i j}+a_{3} \cdot \mathrm{MAT}_{i j}+a_{4} \cdot \operatorname{deMARTONNE}_{i j} \\
& +a_{5} \cdot \text { MixMono }_{i j}+a_{6} \cdot \text { DYEAR }_{i j}+a_{7} \cdot \ln \left(\mathrm{AGE}_{i j k}\right) \cdot \text { ELEVATION }_{i j}+a_{8} \\
& \cdot \ln \left(\mathrm{AGE}_{i j k}\right) \cdot \mathrm{MAT}_{i j}+a_{9} \cdot \ln \left(\mathrm{AGE}_{i j k}\right) \cdot \operatorname{deMARTONNE} E_{i j}+a_{10} \cdot \ln \left(\mathrm{AGE}_{i j k}\right) \\
& \cdot \text { MixMono }_{i j}+a_{11} \cdot \ln \left(\mathrm{AGE}_{i j k}\right) \cdot \text { DYEAR }_{i j}+a_{12} \cdot \text { ELEVATION }_{i j} \cdot \text { MeanTemp }_{i j} \\
& +a_{13} \cdot \text { ELEVATION }_{i j} \cdot \text { deMARTONNE }_{i j}+a_{14} \cdot \text { ELEVATION }_{i j} \cdot \text { MixMono }_{i j}+a_{15} \\
& \cdot \text { ELEVATION }_{i j} \cdot \text { DYEAR }_{i j}+a_{16} \cdot \mathrm{MAT}_{i j} \cdot \text { deMARTONNE }_{i j}+a_{17} \cdot \mathrm{MAT}_{i j} \\
& \cdot \text { MixMono }_{i j}+a_{18} \cdot \mathrm{MAT}_{i j} \cdot \mathrm{DYEAR}_{i j}+a_{19} \cdot \mathrm{deMARTONNE}_{i j} \cdot \text { MixMono }_{i j}+a_{20} \\
& \text { - deMARTONNE } i j \cdot \text { DYEAR }_{i j}+a_{21} \cdot \text { MixMono }_{i j} \cdot \operatorname{DYEAR}_{i j}+b_{i}+b_{i j}+\left(c_{i}+c_{i j}\right) \\
& \cdot \ln \left(\mathrm{AGE}_{i j k}\right)+\varepsilon_{i j k} \text {. }
\end{aligned}
$$


Table 2 Results of fitting the linear mixed effect model from Eq. 2 to the beech in mono-specific plots data

\begin{tabular}{|c|c|c|c|c|}
\hline Fixed effect variable & Fixed effect parameter & Estimate & Std. error & $p$ \\
\hline & $a_{0}$ & 1.2102 & 0.1259 & $<0.0001$ \\
\hline \multirow[t]{8}{*}{$\ln (\mathrm{AGE})$} & $a_{1}$ & $\mathbf{1 . 0 3 7 6}$ & 0.0236 & $<0.0001$ \\
\hline & Random effect & Std. dev. & & \\
\hline & $b_{i}$ & 0.7498 & & \\
\hline & $b_{i j}$ & 0.8511 & & \\
\hline & $c_{i}$ & 0.1389 & & \\
\hline & $c_{i j}$ & 0.1708 & & \\
\hline & Residuals & Std. dev. & & \\
\hline & $\varepsilon_{i j k l}$ & 0.0908 & & \\
\hline
\end{tabular}

AIC comparisons suggested using the full set of random effects. Variable parameters that were significant are in bold (significance level of 0.05)

Table 3 Results of fitting the linear mixed effect model from Eq. 2 to the beech in mixed-mountain-forest plots data

\begin{tabular}{|c|c|c|c|c|}
\hline Fixed effect variable & Fixed effect parameter & Estimate & Std. error & $p$ \\
\hline & $a_{0}$ & 1.3584 & 0.1194 & $<0.0001$ \\
\hline \multirow[t]{8}{*}{$\ln (\mathrm{AGE})$} & $a_{1}$ & 0.9785 & 0.0274 & $<0.0001$ \\
\hline & Random effect & Std. dev. & & \\
\hline & $b_{i}$ & 0.7331 & & \\
\hline & $b_{i j}$ & 0.8889 & & \\
\hline & $c_{i}$ & 0.1706 & & \\
\hline & $c_{i j}$ & 0.1876 & & \\
\hline & Residuals & Std. dev. & & \\
\hline & $\varepsilon_{i j k l}$ & 0.0951 & & \\
\hline
\end{tabular}

AIC comparisons suggested using the full set of random effects. Variable parameters that were significant are in bold (significance level of 0.05 )

The fixed effects in this model cover the main effects $\ln ($ AGE), ELEVATION, MAT deMARTONNE, MixMono (0: mono-specific; 1: mixed), DYEAR and all their twoway interactions. DYEAR (abbreviation for "dbh-year") indicates the calendar year when a given tree reached the height of $1.3 \mathrm{~m}$.

\section{Results}

\section{Linearity of diameter growth over age}

As shown in Tables 2 and 3, the estimates of the fixed effect $a_{1}$ (Eq. 2) for beech in mono-specific stands and beech in mixed-mountain-forest stands were 1.0376 (std. err. 0.0236) and 0.9785 (std. err. 0.0274), respectively. For both, 1 was within the $95 \%$ confidence interval. This indicates no significant deviation from linear diameter growth over age for beech, as illustrated in Fig. 3, with a ranking regarding the steepness of the slope beech mono-specific $>$ beech mixed mountain forests. On average, there was no declining growth trend with age, which would mean a turn towards an asymptotic diameter.

\section{Diameter growth and elevation}

The results obtained by fitting the regression model from Eq. 3 are listed in Table 4. The fixed effect parameters indicated an increase with age. This effect was significant with $p<0.05$. The effects of elevation, mean annual temperature, the de Martonne aridity index and species composition (MixMono) were not significant. However, we found significant positive effects of the interactions between age and elevation, age and mean annual temperature, elevation and species composition (MixMono) and mean annual temperature and species composition. Significant negative effects were found for the interactions between elevation and mean annual temperature and elevation and the de Martonne aridity index. As a result, the growth of beech from both mono-specific stands and mixed stands decreased with increasing elevation (Fig. 4). Although the differences 


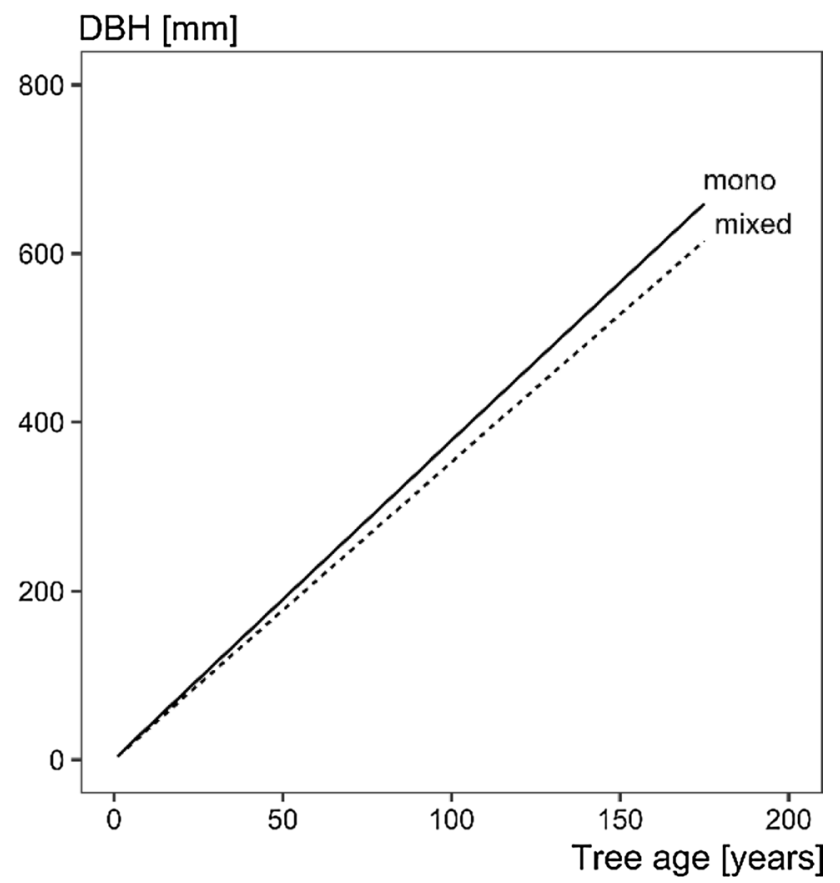

Fig. 3 Mean growth trend for beech during the last century based on the statistical model from Eq. 3. For prediction, elevation and the de Martonne aridity index were kept constant (mean value). On average, there was no declining increment trend with age, which would mean a turn towards an asymptotic diameter. The trend is linear for both with a ranking regarding the steepness of the slope beech mono-specific $>$ beech mixed mountain forests

in growth between elevations were smaller for beech from mixed stands than for beech from mono-specific stands, the growth of beech from mono-specific stands was higher than that of beech from mixed stands up to an elevation of $1000 \mathrm{~m}$ a.s.l. At the highest elevations (> $1300 \mathrm{~m}$ a.s.l.), however, we found higher growth of beech in mixed compared to monospecific stands.

\section{Temporal trends in diameter growth}

We found significant negative effects of elevation and mean annual temperature and a significant positive main effect of species composition (MixMono) on beech growth, indicating a clear elevation trend (Table 5). In addition, there was a significant positive effect of the interaction between age and elevation, age and mean annual temperature, elevation and dbh-year and mean annual temperature and dbh-year. The interaction between species composition and dbh-year had a significant negative effect. Both as a main effect and in the interaction with dbh-year, we could identify a significant effect of species composition (MixMono). The abovementioned trends steepen the diameter-age relationship from 1850 to present, as Fig. 5 shows, for beech from both mono-specific and mixed-species stands, with a stronger trend for beech from mono-specific stands.

\section{Temporal growth trends and elevation}

For beech from mono-specific stands and beech from mixed stands, our results show that the differences in growth at different elevations have become smaller since 1850 (Fig. 6). While beech from mixed stands with a dbh-year of 1850 still showed clear differences in growth between elevations, these differences were hardly visible in beech from mixed stands with a dbh-year of 1950. A similar trend can be seen for beech from pure stands. The larger differences between different elevations of beech trees from mono-specific stands were also reduced, but clear differences in growth were still visible for beech trees with a dbh-year of 1950 . The faster growth of beech from mixed stands compared to beech from pure stands at the highest elevations, as shown in Fig. 4, has not changed since 1850 .

\section{Discussion}

\section{High growth rates and linear diameter development until advanced tree age}

It is well documented that beech can reach longevities of 300-500 years (Ellenberg and Leuschner 2010, p. 104; Di Filippo et al. 2007; Nagel et al. 2014). Although many of the sample trees are approaching this top age, their growth does not yet show a convergence to a maximum stem diameter (Fig. 3). This is in line with the results of Pretzsch et al. (2020b), who found a linear diameter growth trend for Norway spruce, silver fir and beech trees in mixed mountain forests.

This behaviour, however, contradicts the common perception that growth rates (e.g. volume increment $i v$ ) inevitably decrease with increasing tree size $(v)$ due to increasingly unfavourable relationships between the assimilation (which is predicted to increase with tree surface area, $i v \propto v^{2 / 3}$ ) and respiration (depending on volume or mass, $i v \propto v$; von Bertalanffy 1951). Binkley et al. (2002), Franklin and Spies (1984) and Ryan and Waring (1992) showed that respiration can stagnate or even decrease with increasing tree mass; this might be an effect of the shutdown of inner parts of the stem and upper branches. The inner parts may consist of physiologically inactive and dead wood, mainly serving as a scaffolding for the living parts of the tree, and thus, the tree reduces respiration but maintains higher growth rates due to the restricted respiratory losses.

The continuation of a linear rather than an asymptotic course of diameter growth far beyond normal rotation ages (Fig. 3) in both mono- and mixed-species stands may be a 
Table 4 Results of fitting the linear mixed effect model from Eq. 3

\begin{tabular}{|c|c|c|c|c|}
\hline Fixed effect variable & Fixed effect parameter & Estimate & Std. error & $p$ value \\
\hline & $a_{0}$ & 1.4021 & 1.0173 & 0.1681 \\
\hline $\log ($ Age $)$ & $a_{1}$ & 0.6582 & 0.1270 & $<0.0001$ \\
\hline Elevation & $a_{2}$ & 0.0005 & 0.0007 & 0.4193 \\
\hline Mean temperature & $a_{3}$ & 0.0849 & 0.1107 & 0.4458 \\
\hline Aridity & $a_{4}$ & 0.0158 & 0.0113 & 0.1663 \\
\hline MixMono1 & $a_{5}$ & -0.9586 & 0.4920 & 0.0549 \\
\hline $\log ($ Age $) *$ Elevation & $a_{6}$ & 0.0002 & 0.0001 & 0.0050 \\
\hline $\log ($ Age $) *$ Mean temperature & $a_{7}$ & 0.0342 & 0.0126 & 0.0067 \\
\hline $\log ($ Age $) *$ Aridity & $a_{8}$ & -0.0004 & 0.0006 & 0.4894 \\
\hline $\log ($ Age $) *$ MixMono1 & $a_{9}$ & -0.0315 & 0.0386 & 0.4150 \\
\hline Elevation $*$ Mean temperature & $a_{10}$ & -0.0002 & 0.0001 & 0.0088 \\
\hline Elevation* Aridity & $a_{11}$ & -0.0001 & 0.0000 & $\mathbf{0 . 0 3 7 1}$ \\
\hline Elevation * MixMono1 & $a_{12}$ & 0.0003 & 0.0002 & 0.0204 \\
\hline Mean temperature * Aridity & $a_{13}$ & -0.0013 & 0.0011 & 0.2586 \\
\hline Mean temperature * MixMono1 & $a_{14}$ & 0.0845 & 0.0403 & 0.0391 \\
\hline \multirow[t]{8}{*}{ Aridity* MixMono1 } & $a_{15}$ & 0.0037 & 0.0037 & 0.3165 \\
\hline & Random effect & Std. dev. & & \\
\hline & $b_{i}$ & 0.7009 & & \\
\hline & $b_{i j}$ & 0.8419 & & \\
\hline & $c_{i}$ & 0.1506 & & \\
\hline & $c_{i j}$ & 0.1803 & & \\
\hline & Residuals & Std. dev. & & \\
\hline & $\varepsilon_{i j k}$ & 0.0887 & & \\
\hline
\end{tabular}

Note that in the MixMono parameter we used the binary value 0 for mono and 1 for mixed. Variable parameters that were significant are in bold (significance level of 0.05 )

result of the advantageous ratio between assimilation and respiration in advanced age. In addition, the repeatedly reported positive growth trends with accelerating growth even for greater tree ages (Spiecker et al. 2012; Hilmers et al. 2019; Pretzsch et al. 2020b) may cause this linear trend and significant deviation from textbook explanations (e.g. Kramer 1988, p. 66; Bruce and Schumacher 1950, p. 377; Wenk et al. 1990, p. 74; Assmann 1970, p. 80; or Mitscherlich 1970, p. 83). The revealed growth trends may indicate changes in growth conditions in terms of a rise in temperature, extension of the growing season, a rise in atmospheric $\mathrm{CO}_{2}$ level, nitrogen deposition and abandonment of nutrient exporting treatments like litter raking (Kahle 2008; Kauppi et al. 2014; Pretzsch et al. 2014a; Spiecker et al. 2012).

This prolonged increase in growth of old beech trees has implications for stand structure in terms of high growth dominance of old trees, increased diameter differentiation and long-term provision of seed and habitat trees. It also allows for flexibility of silvicultural options (late thinning, extended threshold diameter thinning, extension of regeneration phase) in stands of advanced age.

\section{Faster growth of beech in mixed stands versus mono-specific stands at the edge of its distribution at higher elevations}

One of the most compelling findings was that the course of growth of beech from mono-specific stands was steeper than that of beech in mixed stands up to an elevation of $1000 \mathrm{~m}$ a.s.l. At elevations $>1300 \mathrm{~m}$ a.s.l., however, we found a steeper growth trajectory of beech in mixed compared to mono-specific stands. This intersection between the courses of growth in mono- and mixed-species stands as a function of elevation was indicated by a significant $(p<0.05)$ interaction between the variables MixMono and elevation (see parameter $a_{12}$, Table 4). The growth of beech in mountain forests accelerated in the last century, as in many lowland forests (Spiecker et al. 2012; Pretzsch et al. 2014a, 2020a, b), due to climate change. In the lower mountain forests, the positive growth trends for beech were greater in monoculture than in mixture. However, at higher elevations, at the edge of its previous distribution, beech growth was facilitated in the mixtures.

The mixtures may help to protect beech against frost (Liziniewicz 2009; Kraj and Sztorc 2009), may shade trees 


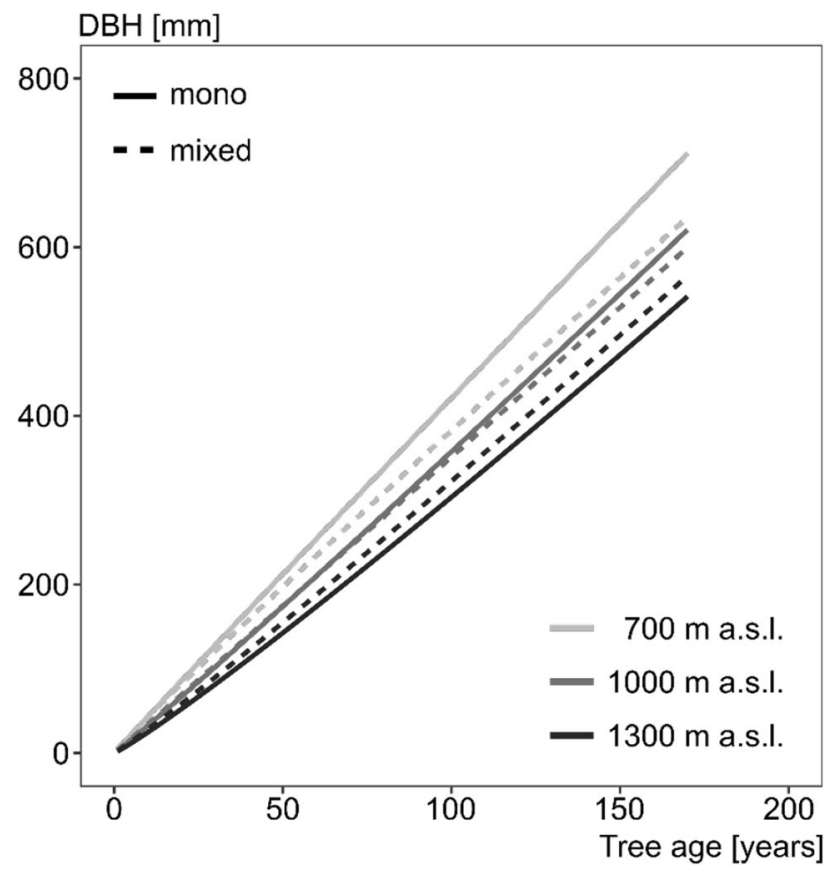

Fig. 4 Diameter-age relationship for beech in mono-specific (solid) and mixed stands (dashed) at different elevations based on the statistical model from Eq. 3. For prediction, the mean annual temperature and the de Martonne aridity index were kept constant (mean value of each elevation class)

from strong radiation and sunburn (Remmert 1991; Fischer 1997), may improve humus and nutrient cycling (Rothe et al. 2002) and improve water supply (Schmid 2002; Goisser et al. 2016). The beech in mono-specific stands may experience less competition for light compared with mixed stands where they may compete with a taller species (Magin 1954; Forrester et al. 2017). Mono-specific stands may be characterized by earlier thawing in spring due to a deeper penetration and higher intensity of radiation before leaf flush; while in mixture with evergreen species, the growing season may start significantly later for beech (Schober 1950; Kantor et al. 2009). We hypothesize that beech grows better in mixed than in mono-specific stands at higher elevations mainly due to less damage from late frost (Zohner et al. 2020). However, a number of different interacting factors that influence beech growth are potentially at play and are likely to vary across environmental conditions and the species mixtures within stands. For example, beech may also be taking advantage of the decline in Norway spruce growth in mixed mountain forests due to damage by bark beetle and drought (Hilmers et al. 2019). Climate change-driven disturbances threaten spruce over virtually its entire range in Europe, and some recent disturbances have, for instance, already reached native subalpine spruce forests close to the timber line in the Alps (Hlásny et al. 2019). Furthermore, evergreen conifers filter out much more eutrophic deposition than broadleaved trees, as they have a higher foliage area that is present for the whole year. This and the faster humus turnover reported in mixed compared to mono-specific stands by Rothe and Binkley (2001) may further contribute to any superiority of beech in mixture, especially in old-growth stages of development.

It is important to note that all these arguments are hypotheses that require further research to understand the growth patterns of beech in mountain forests, particularly the increased growth in mixture at high elevation. Our results are also not entirely consistent with previous studies; Bosela et al. (2015) documented that beech performed better when mixed with spruce and fir than in pure stands at the elevation of 700-800 m a.s.l.

\section{Relevance of beech in mono-specific and mixed mountain forests}

While forests of Alpine environments and Nordic countries are naturally dominated by conifer trees, more diverse mixed-species forests or deciduous forests originally prevailed in mesic lowlands of temperate Europe and in mountain regions at lower elevations of south-central Europe. Indeed, beech is the dominant tree species in large parts of temperate Europe and a typical example of a late-successional canopy tree, including remarkable shade tolerance at early life stages (Nagel et al. 2014; Leuschner and Ellenberg 2017). In areas where beech and mixed mountain forests were transformed into more productive conifer forests, dominated by Norway spruce, recent biotic damage and summer droughts have decreased the productivity of Norway spruce (Marini et al. 2012; Jandl et al. 2019), highlighting the need for alternative forestry systems. Despite its competitive ability and phenotypic plasticity in response to environmental disturbances (Pretzsch and Schütze 2005; Stojnić et al. 2018), beech may also suffer from increasing evaporative demand and decreasing water supply (Tognetti et al. 2019), potentially reducing the productivity of pure stands (Maselli et al. 2014). Use of beech provenances resistant to more frequent droughts and less oceanic environments may provide a strategy to maintain the productivity of pure stands (Bolte et al. 2016).

Besides the direct and indirect effects of changing climate by high temperature (e.g. extreme events, pest outbreaks, forest fires), forest productivity can be reduced by the loss of tree species diversity (Liang et al. 2016). In this context, changing stand structures and species compositions have been suggested as a way to hinder catastrophic shifts of unstable forest stands to degraded forest types, once a threshold is exceeded (Millar and Stephenson 2015; Albrich et al. 2020). Therefore, a transition from pure stands can be facilitated through adaptive management strategies that promote continuous canopy cover, as in structurally diverse forests, with tree species mixtures at different stages of 
Table 5 Results of fitting the linear mixed effect model from Eq. 5

\begin{tabular}{|c|c|c|c|c|}
\hline Fixed effect variable & Fixed effect parameter & Estimate & Std. error & $p$ value \\
\hline & $a_{0}$ & 11.6486 & 7.4233 & 0.1166 \\
\hline $\log ($ Age $)$ & $a_{1}$ & 0.3529 & 0.6508 & 0.5876 \\
\hline Elevation & $a_{2}$ & -0.0076 & 0.0032 & 0.0189 \\
\hline Mean temperature & $a_{3}$ & -2.2591 & 0.6762 & 0.0013 \\
\hline Aridity & $a_{4}$ & -0.0170 & 0.0337 & 0.6160 \\
\hline MixMono1 & $a_{5}$ & 4.6481 & 2.0658 & 0.0272 \\
\hline dbh-year & $a_{6}$ & -0.0047 & 0.0038 & 0.2221 \\
\hline $\log ($ Age $) *$ Elevation & $a_{7}$ & 0.0002 & 0.0001 & 0.0044 \\
\hline $\log ($ Age $) *$ Mean temperature & $a_{8}$ & 0.0339 & 0.0126 & 0.0073 \\
\hline $\log ($ Age $) *$ Aridity & $a_{9}$ & -0.0004 & 0.0007 & 0.5599 \\
\hline $\log ($ Age $) *$ MixMono 1 & $a_{10}$ & -0.0302 & 0.0389 & 0.4366 \\
\hline $\log ($ Age $) *$ dbh-year & $a_{11}$ & 0.0002 & 0.0003 & 0.6359 \\
\hline Elevation* Mean temperature & $a_{12}$ & -0.0001 & 0.0001 & 0.2149 \\
\hline Elevation * Aridity & $a_{13}$ & 0.0000 & 0.0000 & 0.3486 \\
\hline Elevation* MixMono1 & $a_{14}$ & 0.0002 & 0.0002 & 0.2117 \\
\hline Elevation $*$ dbh-year & $a_{15}$ & 0.0001 & 0.0000 & 0.0225 \\
\hline Mean temperature * Aridity & $a_{16}$ & 0.0008 & 0.0009 & 0.4010 \\
\hline Mean temperature $*$ MixMono1 & $a_{17}$ & 0.0351 & 0.0318 & 0.2734 \\
\hline Mean temperature $*$ dbh-year & $a_{18}$ & 0.0011 & 0.0003 & 0.0012 \\
\hline Aridity* MixMono1 & $a_{19}$ & 0.0005 & 0.0029 & 0.8784 \\
\hline Aridity* dbh-year & $a_{20}$ & 0.0000 & 0.0000 & 0.5613 \\
\hline \multirow[t]{8}{*}{ MixMono1 $*$ dbh-year } & $a_{21}$ & -0.0026 & 0.0010 & 0.0121 \\
\hline & Random effect & Std. dev. & & \\
\hline & $b_{i}$ & 0.7059 & & \\
\hline & $b_{i j}$ & 0.8332 & & \\
\hline & $c_{i}$ & 0.1502 & & \\
\hline & $c_{i j}$ & 0.1803 & & \\
\hline & Residuals & Std. dev. & & \\
\hline & $\varepsilon_{i j k}$ & 0.0887 & & \\
\hline
\end{tabular}

Note that in the MixMono parameter we used the binary value 0 for mono and 1 for mixed. Variable parameters that were significant are in bold (significance level of 0.05 )

development and uneven age distributions (e.g. Pommerening and Murphy 2004; Hilmers et al. 2020). The mixture of fir-spruce-beech with an uneven distribution of stem diameters may provide a resilient reference stand type for many forest regions across Europe (Torresan et al. 2020). These mixed-species mountain forests are rather resilient against disturbances and a potential reduction in the volume increment of one species (e.g. Norway spruce or beech) can be compensated for by higher volume increments of another species (e.g. silver fir; Bosela et al. 2018; Hilmers et al. 2019). As a result, fir-spruce-beech mixed forests may be of paramount importance for carbon sequestration in tree biomass and forest soils, contributing to the mitigation of climate change.

\section{Methodological considerations}

One of the limitations of our approach is that we used tree ring data only from trees that now belong to the dominant social class. Although growth of dominant trees may provide good insight into beech growth trends at different elevations and species mixtures, this sampling criteria may result in some bias when generalizing the results and scaling up to the stand level (Forrester 2019). Bias can result because only surviving trees can be sampled and currently dominant trees could have been suppressed in the past (Cherubini et al. 1998), although we tried to mitigate this effect by removing trees showing periods of growth suppression. On the other hand, dominant and suppressed trees can show distinct growth trends and responses to climate (Martín-Benito et al. 2008; Nehrbass-Ahles et al. 


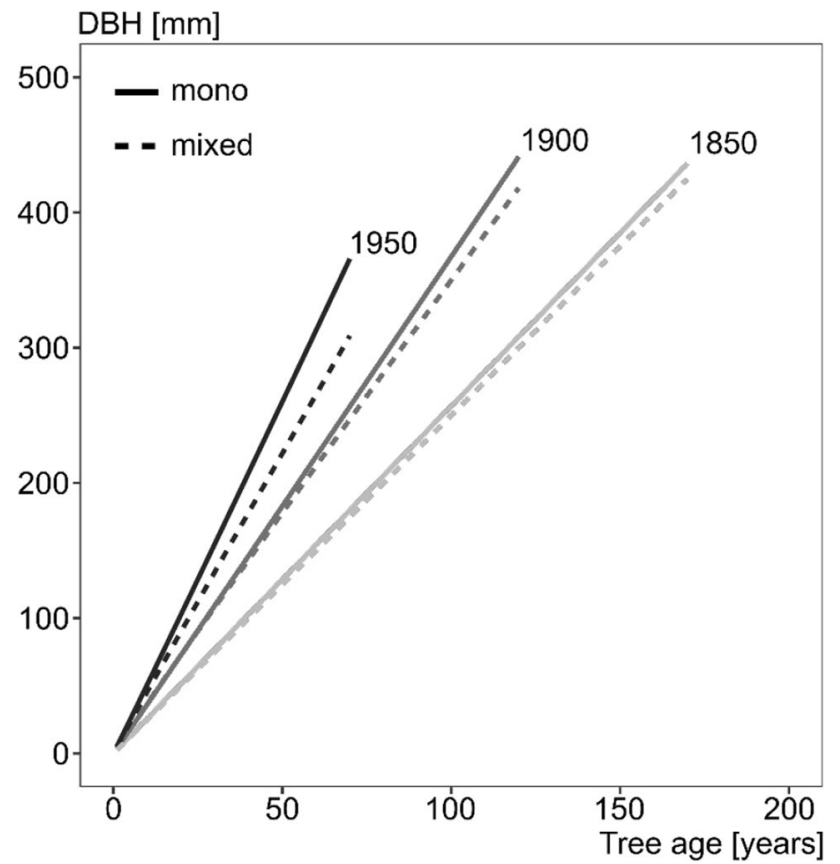

Fig. 5 Diameter-age relationship for beech in mono-specific (solid) and mixed stands (dashed) based on the statistical model from Eq. 5 . dbh-year 1850, 1900, 1950 (abbreviated as DYEAR in Eq. 5) means that the trees reached $1.30 \mathrm{~m}$ height in the year 1850, 1900, 1950 and are 170, 120, 70 years old at present (in 2020). For prediction, elevation a.s.1., mean annual temperature and the de Martonne aridity index were kept constant (mean value)

2014). For shade-tolerant species like beech, dominant trees were found to be more sensitive to climate than suppressed trees (Mérian and Lebourgeois 2011), so that lower temporal changes could be expected at the stand level. However, under more stressful conditions, growth partitioning among trees in beech stands is more size-symmetric (Pretzsch et al. 2018), which suggests the suitability of dominant tree behaviour as an indicator of response to climate change. We selected only fully stocked, unthinned or slightly thinned forest stands for our study. As far as available, we reviewed existing data about the stand history in order to ensure that the stands were unthinned or only slightly thinned in the past. However, we could not guarantee that there were not recorded thinnings in early stand development phases. But notice that any silvicultural interventions would have reduced the stand density and accelerated the tree growth already in the long past, so that the growth trends would even be underestimated. Stronger thinning and growth acceleration of mixed compared with mono-specific stands in the past are unlikely due to the general behaviour in forest practice to thin mono-specific stands for which silvicultural prescriptions were available and to hesitate to intervene in mixed-species stands.

Our plots of mono-specific and mixed stands are not spatially paired (i.e. ceteris paribus conditions) and not evenly

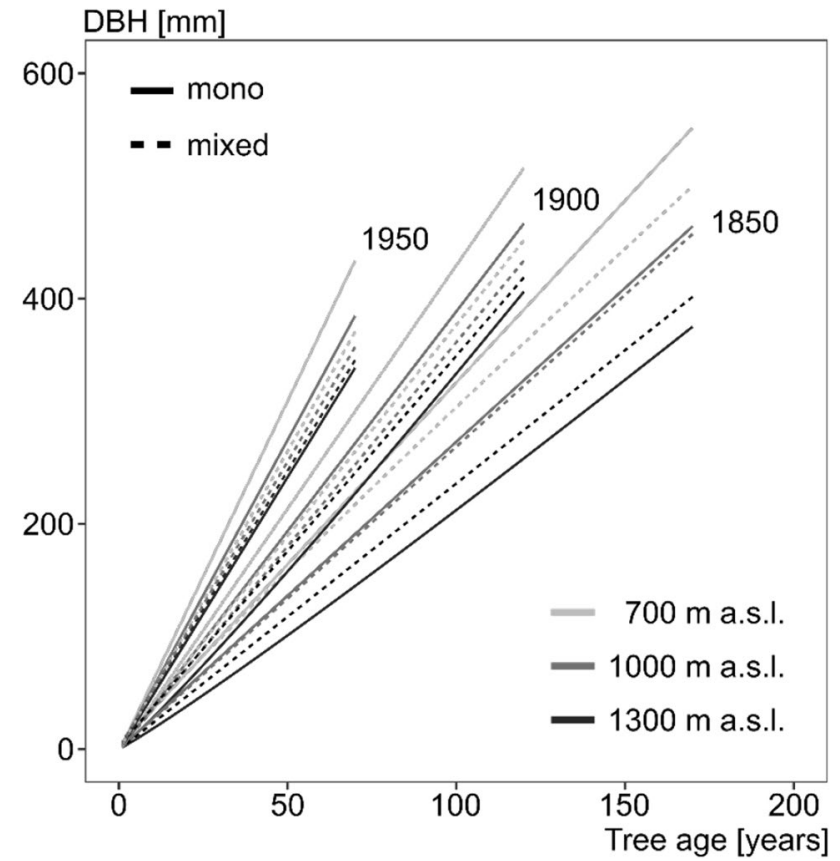

Fig. 6 Diameter-age relationship for beech in mono-specific (solid) and mixed stands (dashed) based on the statistical model from Eq. 5. dbh-year 1850, 1900, 1950 (abbreviated as DYEAR in Eq. 5) means that the trees reached $1.30 \mathrm{~m}$ height in the year 1850, 1900, 1950 and are 170, 120, 70 years old at present (in 2020). For prediction, the mean annual temperature and the de Martonne aridity index were kept constant (mean value of each elevation class)

distributed along the climatic gradient. However, the large variability in site conditions covered by both types of stands (Supplement Table 1) and the large number of trees sampled made the comparison reliable and representative of European beech's growth trends in mountain regions. Nevertheless, the identified mixing effect on growth trends could be partly masked by the different identities of the admixed species, as species interactions vary among different beech mixtures (del Río et al. 2014; Pretzsch and Forrester 2017; Jourdan et al. 2020).

We had no detailed information about soil conditions available. However, ongoing future studies will reveal to what extent variation in field capacity and nutrient availability affects the comparison between mixed and mono-specific stands, tree physiology and growth, including its response to climate conditions.

\section{Relevance of the results for forest management and silviculture}

Our results are relevant for climate-smart close-to-nature silviculture. The potential value of encouraging mixed forests rather than monocultures at high elevations under climate change is indicated by the trend towards increased beech growth in mixtures at higher elevations combined with the recent growth recovery of silver fir at higher elevations 
(Bosela et al. 2018; Hilmers et al. 2019) and reports of Norway spruce problems at lower elevations, caused by extreme events, drought stress and subsequent bark beetle outbreaks (Spiecker 2000). This is also in line with nature conservation directives of NATURA 2000 for protected areas of mountain beech forests (codes 9110-2 and 9130-3), as well as the sustainability approach of providing a full basket of ecosystem services in mountains regions, including wood production, biodiversity, protection against avalanches and soil erosion, water purification and recreation areas.

However, applied silvicultural systems should also consider the different natural ecological role of beech along the elevation gradient. For instance, in the Carpathian Mountains and the foothills of the Alps $(<500-800 \mathrm{~m}$ a.s.1.) forests (if not transformed artificially to spruce monocultures) are usually dominated by very well-performing late-successional beech in admixture with silver fir and/or Norway spruce up to $\sim 20-30 \%$. Here, once in place, very shade-tolerant beech usually obtains canopy closure as the "climax" tree species due to its potential to expand and develop its crowns (Schütz 1998; Bayer et al. 2013; Metz et al. 2016). This changes in the case of the highest subalpine belt ( $>1400-1600 \mathrm{~m}$ a.s.l.) towards its single-tree and group admixture in stands dominated by cold-resistant Norway spruce. When Norway spruce is not present, as in the Pyrenean, beech replaces silver fir (Hernández et al. 2019) while fir replaces beech in the Apennine Mountains (Bonanomi et al. 2020). Nevertheless, all three tree species can successfully coexist at elevations between $\sim 600$ and $1400 \mathrm{~m}$ a.s.l. and create complex uneven-aged balanced mountain mixed forests (Hilmers et al. 2020).

\section{Conclusions}

The long continuation of beech individual tree growth with age will help to maintain high growth rates of dominant old trees, increase diameter differentiation and facilitate the long-term provision of seed and habitat trees. It will also help to stabilize mountain forests and broaden the silvicultural options for their sustainable management. This will help to achieve international commitments (e.g. Paris Agreement) through climate-smart forestry strategies at European, national and local scales (Bowditch et al. 2020), which foster adaptation to environmental disturbances and mitigation of climate change. The acceleration of beech growth in both mono-specific and mixed-species mountain forests will facilitate the development of beech at higher elevations, while beech may lose vitality in the lowlands due to climate change and drought stress. At high elevations beech benefits from growing in inter-specific neighbourhood with species such as fir and spruce. Beneficial interactions with Norway spruce and silver fir may indicate emerging system properties that are often evident in mixed stands, but of special relevance under harsh conditions at the edge of the ecological niche and when extending the previous range as a consequence of environmental change. This study may provide an example of how a trans-regional and transinstitutional data acquisition and evaluation can contribute to better quantifying and understanding the state and dynamics of forest ecosystems under climate change, and the human footprint on ecosystems, while supporting the stewardship for mountain forest ecosystems that provide a multitude of forest ecosystem functions and services worldwide.

Acknowledgements The authors would like to acknowledge networking support by the COST (European Cooperation in Science and Technology) Action CLIMO (Climate-Smart Forestry in Mountain Regions-CA15226) financially supported by the EU Framework Programme for Research and Innovation HORIZON 2020. This publication is part of a project that has received funding from the European Union's HORIZON 2020 research and innovation programme under the Marie Skłodowska-Curie Grant Agreement No 778322. Thanks are also due to the European Union for funding the project 'Mixed species forest management. Lowering risk, increasing resilience (REFORM)' (\# 2816ERA02S under the framework of Sumforest ERA-Net). Further, we would like to thank the Bayerische Staatsforsten (BaySF) for providing the observational plots and to the Bavarian State Ministry of Food, Agriculture, and Forestry for permanent support of the Project W 07 'Long-term experimental plots for forest growth and yield research' (\#7831-26625-2017). We also thank the Forest Research Institute, ERTI Sárvár, Hungary, for assistance and for providing observational plots. Furthermore, our work was partially supported by the SRDA via Project No. APVV-16-0325 and APVV-15-0265, the Ministry of Science and Higher Education of the Republic of Poland, the Project "EVA4.0" No. CZ.02.1.01/0.0/0.0/16_019/0000803 funded by OP RDE and the Project J4-1765 funded by the Slovenian Research Agency and also by the Bulgarian National Science Fund (BNSF) and the Project No. DCOST 01/3/19.10.2018.

Funding Open Access funding enabled and organized by Projekt DEAL.

Open Access This article is licensed under a Creative Commons Attribution 4.0 International License, which permits use, sharing, adaptation, distribution and reproduction in any medium or format, as long as you give appropriate credit to the original author(s) and the source, provide a link to the Creative Commons licence, and indicate if changes were made. The images or other third party material in this article are included in the article's Creative Commons licence, unless indicated otherwise in a credit line to the material. If material is not included in the article's Creative Commons licence and your intended use is not permitted by statutory regulation or exceeds the permitted use, you will need to obtain permission directly from the copyright holder. To view a copy of this licence, visit http://creativecommons.org/licenses/by/4.0/.

\section{References}

Albrich K, Rammer W, Seidl R (2020) Climate change causes critical transitions and irreversible alterations of mountain forests. Glob Change Biol. https://doi.org/10.1111/gcb.15118 
Ammer C, Albrecht L, Borchert H, Brosinger F, Dittmar CH, Elling W, Ewald J, Felbermeier B, Von Gilsa H, Huss J, Kenk G, Kölling $\mathrm{CH}$, Kohnle U, Meyer P, Mosandl R, Moosmayer H-U, Palmer S, Reif A, Rehfuess K-E, Stimm B (2005) Zur Zukunft der Buche (Fagus sylvatica) in Mitteleuropa. Allg Forst-u J-Ztg 176:60-67

Assmann E (1970) The principles of forest yield study. Pergamon Press, Oxford

Bayer D, Seifert S, Pretzsch H (2013) Structural crown properties of Norway spruce (Picea abies [L.] Karst.) and European beech (Fagus sylvatica [L.]) in mixed versus pure stands revealed by terrestrial laser scanning. Trees 27(4):1035-1047. https://doi. org/10.1007/s00468-013-0854-4

Becker A, Bugmann H (2001) Global change and mountain regions - an IGBP initiative for collaborative research. In: Visconti G et al (eds) Global change and protected areas. Advance in Global Change Research, Laquila, Italy, pp 3-9

Bielak K, Dudzińska M, Pretzsch H (2014) Mixed stands of Scots pine (Pinus sylvestris L.) and Norway spruce [Picea abies (L.) Karst] can be more productive than monocultures. Evidence from over 100 years of observation of long-term experiments. For Syst 23(3):573-589

Bigler C, Bugmann H (2018) Climate-induced shifts in leaf unfolding and frost risk of European trees and shrubs. Sci Rep 8(1):1-10

Binkley D, Stape JL, Ryan MG, Barnard HR, Fownes J (2002) Agerelated decline in forest ecosystem growth: an individual-tree, stand-structure hypothesis. Ecosystems 5(1):58-67. https://doi. org/10.1007/s10021-001-0055-7

Bolte A, Czajkowski T, Kompa T (2007) The north-eastern distribution range of European beech-a review. Forestry (London) 80(4):413-429. https://doi.org/10.1093/forestry/cpm028

Bolte A, Hilbrig L, Grundmann B, Kampf F, Brunet J, Roloff A (2010) Climate change impacts on stand structure and competitive interactions in a southern Swedish spruce-beech forest. Eur J For Res 129(3):261-276. https://doi.org/10.1007/s10342-009-0323-1

Bolte A, Czajkowski T, Cocozza C, Tognetti R, de Miguel M, Pšidová E, Ditmarová Ĺ, Dinca L, Delzon S, Cochard H, Ræbild A, de Luis M, Cvjetkovic B, Heiri C, Müller J (2016) Desiccation and mortality dynamics in seedlings of different European beech (Fagus sylvatica L.) populations under extreme drought conditions. Front Plant Sci 7:751. https://doi.org/10.3389/ fpls.2016.00751

Bonanomi G, Zotti M, Mogavero V, Cesarano G, Saulino L, Rita A, Tesei G, Allegrezza M, Saracino A, Allevato E (2020) Climatic and anthropogenic factors explain the variability of Fagus sylvatica treeline elevation in fifteen mountain groups across the Apennines. For Ecosyst 7(1):5. https://doi.org/10.1186/s4066 3-020-0217-8

Bosela M, Tobin B, Šebeň V, Petráš R, Larocque G (2015) Different mixtures of Norway spruce, silver fir, and European beech modify competitive interactions in central European mature mixed forests. Can J For Res 45:1577-1586. https:// doi.org/10.1139/cjfr-2015-0219

Bosela M, Stefančík I, Petráš R, Vacek S (2016) The effects of climate warming on the growth of European beech forests depend critically on thinning strategy and site productivity. Agric For Meteorol 222:21-31. https://doi.org/10.1016/j.agrfo rmet.2016.03.005

Bosela M, Lukac M, Castagneri D, Sedmák R, Biber P, Carrer M, Konôpka B, Nola P, Nagel TA, Popa I, Roibu CC, Svoboda M, Trotsiuk V, Büntgen U (2018) Contrasting effects of environmental change on the radial growth of co-occurring beech and fir trees across Europe. Sci Total Environ 615:1460-1469. https ://doi.org/10.1016/j.scitotenv.2017.09.092

Bowditch E, Santopuoli G, Binder F, del Rio M, La Porta N, Kluvankova T, Lesinski J, Motta R, Pach M, Panzacchi P, Pretzsch H, Temperli C, Tonon G, Smith M, Velikova V, Weatherall A,
Tognetti R (2020) What is climate smart forestry? A definition from a multinational collaborative process focused on mountain regions of Europe. Ecosyst Serv 43:101113. https://doi. org/10.1016/j.ecoser.2020.101113

Bruce D, Schumacher FX (1950) Forest mensuration, 3rd edn. McGraw-Hill, New York, Toronto, London

Brus DJ, Hengeveld GM, Walvoort DJJ, Goedhart PW, Heidema AH, Nabuurs GJ, Gunia K (2012) Statistical mapping of tree species over Europe. Eur J For Res 131(1):145-157. https://doi. org/10.1007/s10342-011-0513-5

Buras A, Menzel A (2019) Projecting tree species composition changes of european forests for 2061-2090 Under RCP 4.5 and RCP 8.5 Scenarios. Front Plant Sci. https://doi.org/10.3389/ fpls.2018.01986

Camarero J, Gazol A, Sangüesa-Barreda G, Cantero A, SánchezSalguero R, Sánchez-Miranda A, Granda E, Serra-Maluquer X, Ibáñez R (2018) Forest growth responses to drought at short-and long-term scales in Spain: squeezing the stress memory from tree rings. Front Ecol Evol 6:9

Cherubini P, Dobbertin M, Innes JL (1998) Potential sampling bias in long-term forest growth trends reconstructed from tree rings: a case study from the Italian Alps. For Ecol Manag 109(1):103118. https://doi.org/10.1016/S0378-1127(98)00242-4

Cocozza C, de Miguel M, Pšidová E, Ditmarová L, Marino S, Maiuro L, Alvino A, Czajkowski T, Bolte A, Tognetti R (2016) Variation in ecophysiological traits and drought tolerance of Beech (Fagus sylvatica L.) seedlings from different populations. Front Plant Sci 7:886. https://doi.org/10.3389/fpls.2016.00886

Collalti A, Trotta C, Keenan TF, Ibrom A, Bond-Lamberty B, Grote R, Vicca S, Reyer CPO, Migliavacca M, Veroustraete F, Anav A, Campioli M, Scoccimarro E, Šigut L, Grieco E, Cescatti A, Matteucci G (2018) Thinning can reduce losses in carbon use efficiency and carbon stocks in managed forests under warmer climate. J Adv Model Earth Syst 10(10):2427-2452. https://doi. org/10.1029/2018MS001275

Cudlín P, Klopčič M, Tognetti R, Malis F, Alados C, Bebi P, Grunewald K, Zhiyanski M, Andonowski V, La Porta N, Bratanova-Doncheva S, Kachaunova E, Edwards-Jonášová M, Ninot J, Rigling A, Hofgaard A, Hlásny T, Skalák P, Wielgolaski F (2017) Drivers of treeline shift in different European mountains. Clim Res 73(1-2):135-150. https://doi.org/10.3354/cr01465

de Martonne E (1926) Une nouvelle function climatologique: L'indice d'aridité. Meteorologie 2:449-459

del Río M, Condés S, Pretzsch H (2014) Analyzing size-symmetric versus size-asymmetric and intra- versus inter-specific competition in beech (Fagus sylvatica L.) mixed stands. For Ecol Manag 325:90-98. https://doi.org/10.1016/j.foreco.2014.03.047

Di Filippo A, Biondi F, Čufar K, De Luis M, Grabner M, Maugeri M, Presutti Saba E, Schirone B, Piovesan G (2007) Bioclimatology of beech (Fagus sylvatica L.) in the Eastern Alps: spatial and altitudinal climatic signals identified through a tree-ring network. J Biogeogr 34(11):1873-1892. https://doi.org/10.111 1/j.1365-2699.2007.01747.x

Dittmar C, Zech W, Elling W (2003) Growth variations of Common beech (Fagus sylvatica L.) under different climatic and environmental conditions in Europe-a dendroecological study. For Ecol Manag 173(1):63-78. https://doi.org/10.1016/S0378 $-1127(01) 00816-7$

Drobyshev I, Övergaard R, Saygin I, Niklasson M, Hickler T, Karlsson M, Sykes MT (2010) Masting behaviour and dendrochronology of European beech (Fagus sylvatica L.) in southern Sweden. For Ecol Manag 259(11):2160-2171

Dulamsuren C, Hauck M, Kopp G, Ruff M, Leuschner C (2017) European beech responds to climate change with growth decline at lower, and growth increase at higher elevations in the center of its distribution range (SW Germany). Trees 31(2):673-686 
Dyderski MK, Paź S, Frelich LE, Jagodziński AM (2018) How much does climate change threaten European forest tree species distributions? Glob Change Biol 24(3):1150-1163. https://doi. org/10.1111/gcb.13925

Eurostat (2018) Industrial roundwood by species: export in Euro. https ://ec.europa.eu/eurostat/en/web/products-datasets/-/FOR_IRSPE $\mathrm{C}$

Ellenberg H, Leuschner C (2010) Vegetation mitteleuropas mit den Alpen: In ökologischer, dynamischer und historischer Sicht, vol 6. Ulmer Verlag, Stuttgart

Fischer A (1997) Vegetation dynamics in European beech forests. Ann Bot. https://doi.org/10.4462/annbotrm-9025

Forrester DI (2015) Transpiration and water-use efficiency in mixedspecies forests versus monocultures: effects of tree size, stand density and season. Tree Physiol 35:289-304. https://doi. org/10.1093/treephys/tpv011

Forrester DI (2019) Linking forest growth with stand structure: tree size inequality, tree growth or resource partitioning and the asymmetry of competition. For Ecol Manag 447:139-157

Forrester DI, Ammer Ch, Annighöfer PJ et al (2017) Predicting the spatial and temporal dynamics of species interactions in Fagus sylvatica and Pinus sylvestris forests across Europe. For Ecol Manag 405:112-133. https://doi.org/10.1016/j.foreco.2017.09.029

Franklin JF, Spies TA (1984) Characteristics of old-growth Douglasfir forests. In: Proceedings of the Society of American Foresters National Convention, pp 10-16

Gallé A, Feller U (2007) Changes of photosynthetic traits in beech saplings (Fagus sylvatica) under severe drought stress and during recovery. Physiol Plant 131(3):412-421. https://doi.org/10.111 1/j.1399-3054.2007.00972.x

Geßler A, Keitel C, Kreuzwieser J, Matyssek R, Seiler W, Rennenberg $\mathrm{H}$ (2007) Potential risks for European beech (Fagus sylvatica L.) in a changing climate. Trees 21(1):1-11. https://doi.org/10.1007/ s00468-006-0107-x

Giuggiola A, Bugmann H, Zingg A, Dobbertin M, Rigling A (2013) Reduction of stand density increases drought resistance in xeric Scots pine forests. For Ecol Manag 310:827-835

Goisser M, Geppert U, Rötzer T, Paya A, Huber A, Kerner R, Bauerle T, Pretzsch H, Pritsch K, Häberle K et al (2016) Does belowground interaction with Fagus sylvatica increase drought susceptibility of photosynthesis and stem growth in Picea abies? For Ecol Manag 375:268-278

Gonzalez de Andres E, Seely B, Blanco JA, Imbert JB, Lo YH, Castillo FJ (2017) Increased complementarity in water-limited environments in Scots pine and European beech mixtures under climate change. Ecohydrology 10(2): e1810

Hacket-Pain AJ, Ascoli D, Vacchiano G et al (2018) Climatically controlled reproduction drives interannual growth variability in a temperate tree species. Ecol Lett 21:1833-1844

Hanewinkel M, Hummel S, Albrecht A (2011) Assessing natural hazards in forestry for risk management: a review. Eur J For Res 130:329-351. https://doi.org/10.1007/s10342-010-0392-1

Harris I, Osborn TJ, Jones P, Lister D (2020) Version 4 of the CRU TS monthly high-resolution gridded multivariate climate dataset. Sci Data 7(1):1-18. https://doi.org/10.1038/s41597-020-0453-3

Hernández L, Camarero JJ, Gil-Peregrín E, Saz Sánchez MÁ, Cañellas I, Montes F (2019) Biotic factors and increasing aridity shape the altitudinal shifts of marginal Pyrenean silver fir populations in Europe. For Ecol Manag 432:558-567. https://doi.org/10.1016/j. foreco.2018.09.037

Hilmers T, Avdagić A, Bartkowicz L, Bielak K, Binder F, Bončina A, Dobor L, Forrester DI, Hobi ML, Ibrahimspahić A, Jaworski A, Klopčič M, Matović B, Nagel TA, Petráš R, del Rio M, Stajić B, Uhl E, Zlatanov T, Tognetti R, Pretzsch H (2019) The productivity of mixed mountain forests comprised of Fagus sylvatica, Picea abies, and Abies alba across Europe. For (London) 92(5):512-522. https://doi.org/10.1093/forestry/cpz035

Hilmers T, Biber P, Knoke T, Pretzsch H (2020) Assessing transformation scenarios from pure Norway spruce to mixed uneven-aged forests in mountain areas. Eur J For Res. https://doi.org/10.1007/ s10342-020-01270-y

Hlásny T, Krokene P, Liebhold A, Montagné-Huck C, Müller J, Qin H, Raffa K, Schelhaas M-J, Seidl R, Svoboda M, Viiri H, European Forest Institute (2019) Living with bark beetles: impacts, outlook and management options. From science to policy. European Forest Institute, Joensuu. https://doi.org/10.36333/fs08

Jandl R, Spathelf P, Bolte A, Prescott CE (2019) Forest adaptation to climate change-is non-management an option? Ann For Sci 76(2):48. https://doi.org/10.1007/s13595-019-0827-x

Jourdan M, Lebourgeois F, Morin X (2019) The effect of tree diversity on the resistance and recovery of forest stands in the French Alps may depend on species differences in hydraulic features. For Ecol Manag 450:117486. https://doi.org/10.1016/j.forec o.2019.117486

Jourdan M, Kunstler G, Morin X (2020) How neighbourhood interactions control the temporal stability and resilience to drought of trees in mountain forests. J Ecol 108:666-677. https://doi. org/10.1111/1365-2745.13294

Juchheim J, Annighöfer P, Ammer C, Calders K, Raumonen P, Seidel D (2017) How management intensity and neighborhood composition affect the structure of beech (Fagus sylvatica $\mathrm{L}$.) trees. Trees 31(5):1723-1735

Jump AS, Hunt JM, Peñuelas J (2006) Rapid climate change-related growth decline at the southern range edge of Fagus sylvatica. Glob Change Biol 12(11):2163-2174. https://doi.org/10.111 $1 / \mathrm{j} .1365-2486.2006 .01250 . \mathrm{x}$

Kahle HP (ed) (2008) Causes and consequences of forest growth trends in Europe: results of the recognition project. Brill, Leiden

Kantor P, Karl Z, Šach F, Černohous V (2009) Analysis of snow accumulation and snow melting in a young mountain spruce and beech stand in the Orlické hory Mts., Czech Republic. J For Sci 55(10):437-451. https://doi.org/10.17221/121/2008-JFS

Kauppi PE, Posch M, Pirinen P (2014) Large impacts of climatic warming on growth of boreal forests since 1960. PLoS ONE 9(11):e111340

Khurshid-Alam FC (1972) Distribution of precipitation in mountainous areas of west Pakistan. In Distribution of precipitation in mountainous areas. Symposium Geilo Norway, July-August 1972. WMO/OMM No. 326, Geneva, Switzerland

Klopčič M, Poljanec A, Dolinar M, Kastelec D, Bončina A (2019) Ice-storm damage to trees in mixed Central European forests: damage patterns, predictors and susceptibility of tree species. For Int J For Res 93:430-443

Kohnle U, Albrecht A, Lenk E, Ohnemus K, Yue C (2014) Growth trends driven by environmental factors extracted from long term experimental data in southwest Germany. Allgemeine Forst-und Jagdzeitung 185(5/6):97-117

Körner C (2003) Alpine plant life: functional plant ecology of high mountain ecosystems; with 47 tables. Springer, Berlin

Körner C (2005) An introduction to the functional diversity of temperate forest trees. In: Forest diversity and function. Springer, Berlin, pp 13-37

Kraj W, Sztorc A (2009) Genetic structure and variability of phenological forms in the European beech (Fagus sylvatica L.). Ann For Sci 66(2):1-7. https://doi.org/10.1051/forest/2008085

Kramer H (1988) Waldwachstumslehre. Paul Parey, Hamburg, Berlin Kramer K, Degen B, Buschbom J, Hickler T, Thuiller W, Sykes MT, de Winter W (2010) Modelling exploration of the future of European beech (Fagus sylvatica L.) under climate change-range, abundance, genetic diversity and adaptive response. For Ecol Manage 259(11):2213-2222 
Kreuzwieser J, Rennenberg H (2014) Molecular and physiological responses of trees to waterlogging stress. Plant Cell Environ 37(10):2245-2259

Lauscher F (1976) Weltweite typen der hohenabhangigkeit des niederschlags. Wetter und Leben 28:80-90

Lebourgeois F, Gomez N, Pinto P, Mérian P (2013) Mixed stands reduce Abies alba tree-ring sensitivity to summer drought in the Vosges mountains, western Europe. Forest Ecol Manag 303:61-71

Leuschner C, Ellenberg H (2017) Ecology of Central European forests: vegetation ecology of Central Europe. Springer, Berlin

Leuschner C, Meier IC, Hertel D (2006) On the niche breadth of Fagus sylvatica: soil nutrient status in 50 Central European beech stands on a broad range of bedrock types. Ann For Sci 63(4):355-368. https://doi.org/10.1051/forest:2006016

Leuzinger S, Zotz G, Asshoff R, Körner C (2005) Responses of deciduous forest trees to severe drought in Central Europe. Tree Physiol 25(6):641-650. https://doi.org/10.1093/treephys/25.6.641

Liang J, Crowther TW, Picard N, Wiser S, Zhou M, Alberti G, Schulze E-D, McGuire AD, Bozzato F, Pretzsch H, de Miguel S, Paquette A, Hérault B, Scherer-Lorenzen M, Barrett CB, Glick HB, Hengeveld GM, Nabuurs G-J, Pfautsch S, Viana H, Vibrans AC, Ammer C, Schall P, Verbyla D, Tchebakova N, Fischer M, Watson JV, Chen HYH, Lei X, Schelhaas M-J, Lu H, Gianelle D, Parfenova EI, Salas C, Lee E, Lee B, Kim HS, Bruelheide H, Coomes DA, Piotto D, Sunderland T, Schmid B, Gourlet-Fleury S, Sonké B, Tavani R, Zhu J, Brandl S, Vayreda J, Kitahara F, Searle EB, Neldner VJ, Ngugi MR, Baraloto C, Frizzera L, Bałazy R, Oleksyn J, Zawiła-Niedźwiecki T, Bouriaud O, Bussotti F, Finér L, Jaroszewicz B, Jucker T, Valladares F, Jagodzinski AM, Peri PL, Gonmadje C, Marthy W, O'Brien T, Martin EH, Marshall AR, Rovero F, Bitariho R, Niklaus PA, AlvarezLoayza P, Chamuya N, Valencia R, Mortier F, Wortel V, EngoneObiang NL, Ferreira LV, Odeke DE, Vasquez RM, Lewis SL, Reich PB (2016) Positive biodiversity-productivity relationship predominant in global forests. Science 354(6309):aaf8957. https ://doi.org/10.1126/science.aaf8957

Liu J-F, Arend M, Yang W-J, Schaub M, Ni Y-Y, Gessler A, Jiang Z-P, Rigling A, Li M-H (2017) Effects of drought on leaf carbon source and growth of European beech are modulated by soil type. Sci Rep 7(1):1-9. https://doi.org/10.1038/srep42462

Liziniewicz M (2009) The development of beech in monoculture and mixtures. SLU, Southern Swedish Forest Research Centre, Alnarp

Magh RK, Bonn B, Grote R, Burzlaff T, Pfautsch S, Rennenberg H (2019) Drought superimposes the positive effect of Silver Fir on water relations of European beech in mature forest stands. Forests 10(10):897

Magin R (1954) Ertragskundliche Untersuchungen in montanen Mischwäldern. Forstwissenschaftliches Centralblatt 73(3-4):103-113

Marini L, Ayres MP, Battisti A, Faccoli M (2012) Climate affects severity and altitudinal distribution of outbreaks in an eruptive bark beetle. Clim Change 115(2):327-341. https://doi.org/10.1007/ s10584-012-0463-z

Martín-Benito D, Cherubini P, del Río M, Cañellas I (2008) Growth response to climate and drought in Pinus nigra Arn. Trees of different crown classes. Trees 22(3):363-373. https://doi. org/10.1007/s00468-007-0191-6

Maselli F, Cherubini P, Chiesi M, Gilabert MA, Lombardi F, Moreno A, Teobaldelli M, Tognetti R (2014) Start of the dry season as a main determinant of inter-annual Mediterranean forest production variations. Agric For Meteorol 194:197-206. https://doi. org/10.1016/j.agrformet.2014.04.006

Matyssek R, Wieser G, Ceulemans R, Rennenberg H, Pretzsch H, Haberer K, Löw M, Nunn AJ, Werner H, Wipfler P, Oßwald
W (2010) Enhanced ozone strongly reduces carbon sink strength of adult beech (Fagus sylvatica) - resume from the free-air fumigation study at Kranzberg Forest. Environ Poll 158(8):2527-2532

Mausolf K, Wilm P, Härdtle W, Jansen K, Schuldt B, Sturm K, von Oheimb G, Hertel D, Leuschner C, Fichtner A (2018) Higher drought sensitivity of radial growth of European beech in managed than in unmanaged forests. Sci Total Environ 642:12011208. https://doi.org/10.1016/j.scitotenv.2018.06.065

Mérian P, Lebourgeois F (2011) Size-mediated climate-growth relationships in temperate forests: a multi-species analysis. For Ecol Manag 261(8):1382-1391. https://doi.org/10.1016/j.forec o.2011.01.019

Metz J, Annighöfer P, Schall P, Zimmermann J, Kahl T, Schulze E-D, Ammer C (2016) Site-adapted admixed tree species reduce drought susceptibility of mature European beech. Glob Change Biol 22(2):903-920. https://doi.org/10.1111/gcb.13113

Millar CI, Stephenson NL (2015) Temperate forest health in an era of emerging megadisturbance. Science 349(6250):823-826. https ://doi.org/10.1126/science.aaa9933

Mitscherlich G (1970) Wald, Wachstum und Umwelt: Form und Wachstum von Baum und Bestand. JD Sauerländers Verlag, Bad Orb

Nagel TA, Svoboda M, Kobal M (2014) Disturbance, life history traits, and dynamics in an old-growth forest landscape of southeastern Europe. Ecol Appl 24(4):663-679. https://doi. org/10.1890/13-0632.1

Nehrbass-Ahles C, Babst F, Klesse S, Nötzli M, Bouriaud O, Neukom R, Dobbertin M, Frank D (2014) The influence of sampling design on tree-ring-based quantification of forest growth. Glob Change Biol 20(9):2867-2885. https://doi.org/10.1111/ gcb.12599

Paul C, Brandl S, Friedrich S et al (2019) Climate change and mixed forests: how do altered survival probabilities impact economically desirable species proportions of Norway spruce and European beech? Ann For Sci 76:14. https://doi.org/10.1007/s1359 5-018-0793-8

Pflug EE, Buchmann N, Siegwolf RTW, Schaub M, Rigling A, Arend M (2018) Resilient leaf physiological response of European beech (Fagus sylvatica L.) to summer drought and drought release. Front Plant Sci 9:187. https://doi.org/10.3389/ fpls.2018.00187

Pinheiro J, Bates D, DebRoy S, Sarkar D, R Core Team (2020) nlme: linear and nonlinear mixed effects models. https://CRAN.R-proje ct.org $/$ package $=$ nlme

Piovesan G, Biondi F, Filippo AD, Alessandrini A, Maugeri M (2008) Drought-driven growth reduction in old beech (Fagus sylvatica L.) forests of the central Apennines, Italy. Glob Change Biol 14(6):1265-1281. https://doi.org/10.111 $1 / \mathrm{j} .1365-2486.2008 .01570 . \mathrm{x}$

Poljanec A, Ficko A, Boncina A (2010) Spatiotemporal dynamic of European beech (Fagus sylvatica L.) in Slovenia, 1970-2005. For Ecol Manag 259(11):2183-2190

Pommerening A, Murphy ST (2004) A review of the history, definitions and methods of continuous cover forestry with special attention to afforestation and restocking. Forestry (London) 77(1):27-44. https://doi.org/10.1093/forestry/77.1.27

Pretzsch H (2009) Forest dynamics, growth and yield. Springer, Berlin, Heidelberg, p 664

Pretzsch H (2019) Transitioning monocultures to complex forest stands in Central Europe: principles and practice. In: Stanturf JA (ed) Achieving sustainable management of boreal and temperate forests. Burleigh Dodds Science Publishing, Cambridge. ISBN 978 1786762924

Pretzsch H (2020) The course of tree growth. Theory and reality. For Ecol Manag 478:118508 
Pretzsch H, Forrester DI (2017) Stand dynamics of mixed-species stands compared with monocultures. In: Pretzsch H, Forrester DI, Bauhus J (eds) Mixed-species forests-ecology and management. Springer, Berlin, Heidelberg, pp 117-209

Pretzsch H, Schütze G (2005) Crown allometry and growing space efficiency of Norway spruce (Picea abies [L.] Karst.) and European beech (Fagus sylvatica L.) in pure and mixed stands. Plant Biol (Stuttgart) 7(6):628-639. https://doi.org/10.1055/s-2005-865965

Pretzsch H, Schütze G (2018) Growth recovery of mature Norway spruce and European beech from chronic $\mathrm{O}_{3}$ stress. Eur J For Res 137(2):251-263

Pretzsch H, Dieler J, Matyssek R, Wipfler P (2010) Tree and stand growth of mature Norway spruce and European beech under long-term ozone fumigation. Environ Poll 158(4):1061-1070

Pretzsch H, Schütze G, Uhl E (2013) Resistance of European tree species to drought stress in mixed pure forests: evidence of stress release by inter-specific facilitation. Plant Biol 15(3):483-495

Pretzsch H, Biber P, Schütze G, Uhl E, Rötzer T (2014a) Forest stand growth dynamics in Central Europe have accelerated since 1870. Nat Commun 5:4967. https://doi.org/10.1038/ncomms5967

Pretzsch H, Rötzer T, Matyssek R, Grams TEE, Häberle K-H, Pritsch K, Kerner R, Munch J-C (2014b) Mixed Norway spruce (Picea abies [L.] Karst) and European beech (Fagus sylvatica [L.]) stands under drought: from reaction pattern to mechanism. Trees 28:1305-1321. https://doi.org/10.1007/s00468-014-1035-9

Pretzsch H, Biber P, Uhl E, Dauber E (2015a) Long-term stand dynamics of managed spruce-fir-beech mountain forests in Central Europe: structure, productivity and regeneration success. Forestry (London) 88(4):407-428. https://doi.org/10.1093/forestry/ cpv013

Pretzsch H, del Río M, Ammer C, Avdagic A, Barbeito I, Bielak K, Brazaitis G, Coll L, Dirnberger G, Drössler L, Fabrika M, Forrester DI, Godvod K, Heym M, Hurt V, Kurylyak V, Löf M, Lombardi F, Matović B, Mohren F, Motta R, den Ouden J, Pach M, Ponette Q, Schütze G, Schweig J, Skrzyszewski J, Sramek V, Sterba H, Stojanović D, Svoboda M, Vanhellemont M, Verheyen K, Wellhausen K, Zlatanov T, Bravo-Oviedo A (2015b) Growth and yield of mixed versus pure stands of Scots pine (Pinus sylvestris L.) and European beech (Fagus sylvatica L.) analysed along a productivity gradient through Europe. Eur J For Res 134:927-947. https://doi.org/10.1007/s10342-015-0900-4

Pretzsch H, Schütze G, Biber P (2018) Drought can favour the growth of small in relation to tall trees in mature stands of Norway spruce and European beech. For Ecosyst 5(1):20

Pretzsch H, Grams T, Häberle KH, Pritsch K, Bauerle T, Rötzer T (2020a) Growth and mortality of Norway spruce and European beech in monospecific and mixed-species stands under natural episodic and experimentally extended drought. Results of the KROOF throughfall exclusion experiment. Trees. https://doi. org/10.1007/s00468-020-01973-0

Pretzsch H, Hilmers T, Biber P, Avdagic A, Binder F, Bončina A, Bosela M, Dobor L, Forrester DI, Lévesque M, Ibrahimspahić A, Nagel TA, del Rio M, Sitkova Z, Schütze G, Stajić B, Stojanović D, Uhl E, Zlatanov T, Tognetti R (2020b) Evidence of elevationspecific growth changes of spruce, fir, and beech in European mixed-mountain forests during the last three centuries. Can J For Res 50(7):689-703

R Core Team (2020) R: a language and environment for statistical computing. R Foundation for Statistical Computing, Vienna. https:// www.R-project.org/

Rabasa SG, Granda E, Benavides R, Kunstler G, Espelta JM, Ogaya R, Peñuelas J, Scherer-Lorenzen M, Gil W, Grodzki W, Ambrozy S, Bergh J, Hódar J, Zamora R, Valladares F (2013) Disparity in elevational shifts of European trees in response to recent climate warming. Glob Change Biol 19(8):2490-2499
Remmert H (1991) The mosaic-cycle concept of ecosystems-an overview. In: Remmert H (ed) The mosaic-cycle concept of ecosystems. Springer, Berlin, pp 1-21. https://doi.org/10.1007/978-3642-75650-4_1

Rennenberg H, Seiler W, Matyssek R, Gessler A, Kreuzwieser J (2004) Die Buche (Fagus sylvatica L.)-ein Waldbaum ohne Zukunft im südlichen Mitteleuropa. Allgemeine Forst-und Jagdzeitung 175(10-11):210-224

Rothe A, Binkley D (2001) Nutritional interactions in mixed species forests: a synthesis. Can J For Res 31(11):1855-1870. https:// doi.org/10.1139/x01-120

Rothe A, Kreutzer K, Küchenhoff H (2002) Influence of tree species composition on soil and soil solution properties in two mixed spruce-beech stands with contrasting history in Southern Germany. Plant Soil 240(1):47-56. https://doi.org/10.1023/A:10158 22620431

Rötzer T, Liao Y, Goergen K, Schüler G, Pretzsch H (2013) Modelling the impact of climate change on the productivity and water-use efficiency of a central European beech forest. Clim Res 58(1):81-95

Ryan MG, Waring RH (1992) Maintenance respiration and stand development in a subalpine lodgepole pine forest. Ecology 73(6):2100-2108. https://doi.org/10.2307/1941458

Scharnweber T, Manthey M, Criegee C, Bauwe A, Schröder C, Wilmking M (2011) Drought matters-declining precipitation influences growth of Fagus sylvatica L. and Quercus robur L. in north-eastern Germany. For Ecol Manag 262(6):947-961

Scharnweber T, Manthey M, Wilmking M (2013) Differential radial growth patterns between beech (Fagus sylvatica L.) and oak (Quercus robur L.) on periodically waterlogged soils. Tree Physiol 33(4):425-437

Scharnweber T, Heußner KU, Smiljanic M, Heinrich I, van der MaatenTheunissen M, van der Maaten E, Struwe T, Buras A, Wilmking M (2019) Removing the no-analogue bias in modern accelerated tree growth leads to stronger medieval drought. Sci Rep $9(1): 1-10$

Schmid I (2002) The influence of soil type and interspecific competition on the fine root system of Norway spruce and European beech. Basic Appl Ecol 3(4):339-346. https://doi. org/10.1078/1439-1791-00116

Schober R (1950) Zum jahreszeitlichen Ablauf des sekundären Dickenwachstums. Allgemeine Forst-und Jagdzeitung 122:81-96

Schuldt B, Knutzen F, Delzon S, Jansen S, Müller-Haubold H, Burlett R, Clough Y, Leuschner C (2016) How adaptable is the hydraulic system of European beech in the face of climate change-related precipitation reduction? New Phytol 210(2):443-458. https://doi. org/10.1111/nph.13798

Schütz J (1998) Behandlungskonzepte der Buche aus heutiger Sicht. Schweizerische Zeitschrift für Forstwesen 149:1005-1030

Spiecker H (2000) Growth of Norway spruce [Picea abies (L.) Karst.] under changing environmental conditions in Europe. In: Klimo E, Hager H, Kulhavy J (eds) Spruce monocultures in Central Europe: problems and prospects. European Forest Institute proceedings, vol 33. European Forest Institute, Joensuu, pp 11-26

Spiecker H, Mielikäinen K, Köhl M, Skovsgaard JP (2012) Growth trends in European forests: studies from 12 countries. Springer, Berlin

Stojnić S, Suchocka M, Benito-Garzón M, Torres-Ruiz JM, Cochard H, Bolte A, Cocozza C, Cvjetković B, de Luis M, Martinez-Vilalta J, Ræbild A, Tognetti R, Delzon S (2018) Variation in xylem vulnerability to embolism in European beech from geographically marginal populations. Tree Physiol 38(2):173-185. https ://doi.org/10.1093/treephys/tpx128

Sykes M, Prentice I (1995) Boreal forest futures: modelling the controls on tree species range limits and transient responses to climate change. Water Air Soil Pollut 82(1-2):415-428 
Tegel W, Seim A, Hakelberg D, Hoffmann S, Panev M, Westphal T, Büntgen U (2014) A recent growth increase of European beech (Fagus sylvatica L.) at its Mediterranean distribution limit contradicts drought stress. Eur J Forest Res 133(1):61-71. https:// doi.org/10.1007/s10342-013-0737-7

Thurm EA, Pretzsch H (2016) Improved productivity and modified tree morphology of mixed versus pure stands of European beech (Fagus sylvatica) and Douglas-fir (Pseudotsuga menziesii) with increasing precipitation and age. Ann For Sci 73(4):1047-1061. https://doi.org/10.1007/s13595-016-0588-8

Tognetti R, Michelozzi M, Borghetti M (1994) Response to light of shade-grown beech seedlings subjected to different watering regimes. Tree Physiol 14((7-8-9)):751-758. https://doi. org/10.1093/treephys/14.7-8-9.751

Tognetti R, Johnson JD, Michelozzi M (1995) The response of European beech (Fagus sylvatica L.) seedlings from two Italian populations to drought and recovery. Trees 9(6):348-354. https://doi. org/10.1007/BF00202499

Tognetti R, Lombardi F, Lasserre B, Cherubini P, Marchetti M (2014) Tree-ring stable isotopes reveal twentieth-century increases in water-use efficiency of Fagus sylvatica and Nothofagus spp. in Italian and Chilean mountains. PLoS ONE. https://doi. org/10.1371/journal.pone.0113136

Tognetti R, Lasserre B, Di Febbraro M, Marchetti M (2019) Modeling regional drought-stress indices for beech forests in Mediterranean mountains based on tree-ring data. Agric For Meteorol 265:110-120. https://doi.org/10.1016/j.agrformet.2018.11.015

Torresan C, del Río M, Hilmers T, Notarangelo M, Bielak K, Binder F, Boncina A, Bosela M, Forrester DI, Hobi ML, Nagel TA, Bartkowicz L, Sitkova Z, Zlatanov T, Tognetti R, Pretzsch H (2020) Importance of tree species size dominance and heterogeneity on the productivity of spruce-fir-beech mountain forest stands in Europe. For Ecol Manag 457:117716. https://doi.org/10.1016/j. foreco.2019.117716

Trotsiuk V, Hartig F, Cailleret M, Babst F, Forrester DI, Baltensweiler A, Buchmann N, Bugmann H, Gessler A, Gharun M, Minunno F, Rigling A, Rohner B, Stillhard J, Thuerig E, Waldner P, Ferretti M, Eugster W, Schaub M (2020) Assessing the response of forest productivity to climate extremes in Switzerland using model-data fusion. Glob Change Biol 26:2463-2476

Trouvé R, Bontemps JD, Collet C, Seynave I, Lebourgeois F (2017) Radial growth resilience of sessile oak after drought is affected by site water status, stand density, and social status. Trees 31(2):517-529 van der Werf GW, Sass-Klaassen UGW, Mohren GMJ (2007) The impact of the 2003 summer drought on the intra-annual growth pattern of beech (Fagus sylvatica L.) and oak (Quercus robur L.) on a dry site in the Netherlands. Dendrochronologia 25(2):103112. https://doi.org/10.1016/j.dendro.2007.03.004

Vitasse Y, Lenz A, Körner C (2014) The interaction between freezing tolerance and phenology in temperate deciduous trees. Front Plant Sci 5:541

von Bertalanffy L (1951) Theoretische Biologie: II. Band, Stoffwechsel, Wachstum. Francke, Bern

Vukelić J, Baričević D, Pernar N, Bakšić D, Racić D, Vrbek B (2008) Phytocoenological-pedological features of subalpine beech forests (as. Ranunculo platanifoliae-Fagetum Marinček et al. 1993) on northern Velebit. Period Biol 110(2):163-171

Wenk G, Antanaitis V, Šmelko Š (1990) Waldertragslehre. Dt. Landwirtschaftsverl, Berlin

Wipfler P, Seifert T, Heerdt C, Werner H, Pretzsch H (2005) Growth of adult Norway spruce (Picea abies [L.] Karst.) and European beech (Fagus sylvatica $\mathrm{L}$.) under free-air ozone fumigation. Plant Biol 7:611-618. https://doi.org/10.1055/s-2005-872871

Zang C, Hartl-Meier C, Dittmar C, Rothe A, Menzel A (2014) Patterns of drought tolerance in major European temperate forest trees: climatic drivers and levels of variability. Glob Change Biol 20(12):3767-3779. https://doi.org/10.1111/gcb.12637

Zeller L, Pretzsch H (2019) Effect of forest structure on stand productivity in Central European forests depends on developmental stage and tree species diversity. For Ecol Manag 434:193-204. https://doi.org/10.1016/j.foreco.2018.12.024

Zohner CM, Mo L, Renner SS, Svenning JC, Vitasse Y, Benito BM, Ordonez A, Baumgarten F, Bastin JF, Sebald V, Reich PB, Liang J, Nabuurs G-J, de Miguel S, Alberti G, Antón-Fernández A, Balazy R, Brändli U-B, Chen HYH, Chisholm C, Cienciala E, Dayanandan S, Fayle TM, Frizzera L, Gianelle D, Jagodzinski AM, Jaroszewicz BJ, Jucker T, Kepfer-Rojas S, Khan ML, Kim HS, Korjus H, Johannsen VK, Laarmann D, Lang M, ZawilaNiedzwiecki T, Niklaus PA, Paquette A, Pretzsch H, Saikia P, Schall P, Šebeň V, Svoboda M, Tikhonova E, Viana H, Zhang C, Zhao X, Crowther TW (2020) Late-spring frost risk between 1959 and 2017 decreased in North America but increased in Europe and Asia. Proc Nat Acad Sci 117(22):12192-12200

Publisher's Note Springer Nature remains neutral with regard to jurisdictional claims in published maps and institutional affiliations.

\title{
Affiliations
}

\author{
Hans Pretzsch ${ }^{1}$ - Torben Hilmers ${ }^{1} \cdot$ Enno Uhl $^{1,2} \cdot$ Kamil Bielak $^{3} \cdot$ Michal Bosela $^{4,5} \cdot$ Miren del Rio $^{6,7} \cdot$ Laura Dobor $^{8}$. \\ David I. Forrester ${ }^{9} \cdot$ Thomas A. Nagel $^{10} \cdot$ Maciej Pach $^{11} \cdot$ Admir Avdagić $^{12} \cdot$ Michal Bellan $^{13,14}$. Franz Binder $^{2}$. \\ Andrej Bončina ${ }^{10}$. Felipe Bravo ${ }^{7}$. Javier de-Dios-García ${ }^{15}$. Lucian Dinca $^{16}$. Stanisław Drozdowski ${ }^{3}$. \\ Francesco Giammarchi ${ }^{17} \cdot$ Maria Hoehn ${ }^{18} \cdot$ Aida Ibrahimspahić ${ }^{12} \cdot$ Andrzej Jaworski $^{11} \cdot$ Matija Klopčič $^{10}$. \\ Viktor Kurylyak $^{19}$ - Mathieu Lévesque ${ }^{20} \cdot$ Fabio Lombardi $^{21}$ - Bratislav Matović ${ }^{22,23}$. Cristóbal Ordóñez ${ }^{7,24}$. \\ Rudolf Petrášs ${ }^{25}$. Alvaro Rubio-Cuadrado ${ }^{26}$. Dejan Stojanovic ${ }^{22}$ • Jerzy Skrzyszewski ${ }^{11}$ • Branko Stajić ${ }^{27}$.

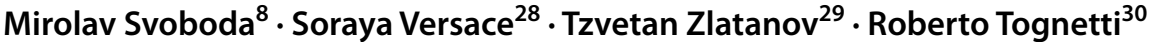

1 Chair of Forest Growth and Yield Science, School of Life Sciences Weihenstephan, Technical University of Munich, Hans-Carl-von-Carlowitz-Platz 2, 85354 Freising, Germany

2 Bavarian State Institute of Forestry (LWF), Hans-Carl-von-Carlowitz-Platz 1, 85354 Freising, Germany

3 Department of Silviculture, Institute of Forest Sciences, Warsaw University of Life Sciences, Nowoursynowska 159/34, 02776 Warsaw, Poland 
4 Department of Forest Management and Geodesy, Technical University in Zvolen, Zvolen, Slovakia

5 Department of Forest Landscape and Ecology, National Forest Centre, Zvolen, Slovakia

6 INIA, Forest Research Centre, Crta. La Coruña km 7,5, 28040 Madrid, Spain

7 iuFOR, Sustainable Forest Management Research Institute, University of Valladolid \& INIA, Palencia, Spain

8 Faculty of Forestry and Wood Sciences, Czech University of Life Sciences Prague, Kamýcká 129, 16521 Prague 6, Czech Republic

9 Swiss Federal Institute of Forest, Snow and Landscape Research WSL, Zürcherstrasse 111, 8903 Birmensdorf, Switzerland

10 Department of Forestry and Renewable Forest Resources, Biotechnical Faculty, University of Ljubljana, Večna pot 83, 1000 Ljubljana, Slovenia

11 Department of Forest Ecology and Silviculture, Faculty of Forestry, University of Agriculture in Krakow, Kraków, Poland

12 Chair of Forest Management and Urban Greenery, Faculty of Forestry, University of Sarajevo, Zagrebačka 20, 71000 Sarajevo, Bosnia and Herzegovina

13 Department of Forest Ecology, Faculty of Forestry and Wood Technology, Mendel University in Brno, Brno, Czech Republic

14 Global Change Research Institute of the Czech Academy of Sciences, Bělidla 4a, 60300 Brno, Czech Republic

15 AGROTECNIOForest Science and Technology Centre of Catalonia (CTFC), Solsona, Spain

16 National Institute for Research and Development in Forestry (INCDS) "Marin Drăcea", Voluntari, Romania

17 Faculty of Science and Technology, Free University of Bolzano-Bozen, Piazza Università 1, 39100 Bolzano, Italy
18 Department of Botany, Faculty of Horticultural Science, SZIU, Budapest, Hungary

19 Institute of Forestry and Horticulture, Ukrainian National Forestry University, L'viv, Ukraine

20 Forest Ecology, Department of Environmental Systems Science, ETH Zurich, Zurich, Switzerland

21 Dipartimento di Agraria, Università Mediterranea di Reggio Calabria, Loc. Feo di Vito, 89122 Reggio Calabria, Italy

22 Institute of Lowland Forestry and Environment, University of Novi Sad, Antona Čehova 13, 21000 Novi Sad, Serbia

23 Faculty of Agriculture, University of East Sarajevo, Vuka Karadžića 30, 71123 Istočno Sarajevo, Republika Srpska, Bosnia and Herzegovina

24 Departamento de Producción Vegetal, Universidad de Valladolid, Palencia, Spain

25 National Forest Centre, T. G. Masaryka 22, 96092 Zvolen, Slovakia

26 Departamento de Sistemas y Recursos Naturales, Escuela Técnica Superior de Ingeniería de Montes, Forestal y del Medio Natural, Universidad Politécnica de Madrid, Madrid, Spain

27 Faculty of Forestry, University of Belgrade, Kneza Višeslava 1, 11030 Belgrade, Serbia

28 Dipartimento di Bioscienze e Territorio, Università degli studi del Molise, 86090 Pesche, IS, Italy

29 Institute of Biodiversity and Ecosystem Research, Bulgarian Academy of Sciences, 2 Gagarin Street, 1113 Sofia, Bulgaria

30 Dipartimento di Agricoltura, Ambiente e Alimenti, Università degli Studi del Molise, Via Francesco De Sanctis, 86100 Campobasso, Italy 